\title{
Article \\ Effect of Greenhouse Cladding Materials and Thermal Screen Configuration on Heating Energy and Strawberry (Fragaria ananassa var. "Seolhyang") Yield in Winter
}

\author{
Timothy Denen Akpenpuun 1,2@ , Wook-Ho Na ${ }^{2}$, Qazeem Opeyemi Ogunlowo ${ }^{3,4}\left(\mathbb{D}\right.$, Anis Rabiu ${ }^{3} \mathbb{C}$, \\ Misbaudeen Aderemi Adesanya ${ }^{3}\left(\mathbb{D}\right.$, Kwame Sasu Addae ${ }^{5}$, Hyeon-Tae Kim ${ }^{6} \mathbb{D}$ and Hyun-Woo Lee ${ }^{2,3, *(D)}$ \\ 1 Department of Agricultural and Biosystems Engineering, University of Ilorin, Ilorin 240003, Nigeria; \\ akpenpuun.td@unilorin.edu.ng \\ 2 Smart Agriculture Innovation Center, Kyungpook National University, Daegu 41566, Korea; \\ wooks121@yahoo.co.kr \\ 3 Department of Agricultural Civil Engineering, College of Agricultural \& Life Sciences, \\ Kyungpook National University, Daegu 702701, Korea; cosmosopy@yahoo.com (Q.O.O.); \\ rabiuanis@gmail.com (A.R.); misbauadesanya@gmail.com (M.A.A.) \\ 4 Department of Agricultural and Bioenvironmental Engineering, Federal College of Agriculture, \\ Moor Plantation, Ibadan PMB 5029, Nigeria \\ 5 Department of Agriculture, Kwahu South Municipal, Kwahu, Mpraeso P.O. Box mp 26, Ghana; \\ kwameaddae1435@gmail.com \\ check for \\ updates \\ Citation: Akpenpuun, T.D.; Na, \\ 6 Department of Bio-Industrial Machinery Engineering, Gyeongsang National University, Jinju 52828, Korea; \\ bioani@gnu.ac.kr \\ * Correspondence: whlee@knu.ac.kr; Tel.: +82-53-850-5736
} W.-H.; Ogunlowo, Q.O.; Rabiu, A.; Adesanya, M.A.; Addae, K.S.; Kim, H.-T.; Lee, H.-W. Effect of Greenhouse Cladding Materials and Thermal Screen Configuration on Heating Energy and Strawberry (Fragaria ananassa var. "Seolhyang") Yield in Winter. Agronomy 2021, 11, 2498. https://doi.org/10.3390/ agronomy 11122498

Academic Editors: Jouke Campen, Feije de Zwart and Nazim Gruda

Received: 20 October 2021

Accepted: 6 December 2021

Published: 9 December 2021

Publisher's Note: MDPI stays neutral with regard to jurisdictional claims in published maps and institutional affiliations.

Copyright: (c) 2021 by the authors Licensee MDPI, Basel, Switzerland. This article is an open access article distributed under the terms and conditions of the Creative Commons Attribution (CC BY) license (https:// creativecommons.org/licenses/by/ $4.0 /)$.
Abstract: Strawberry cultivation depends on environmental factors, making its cultivation in the greenhouse a challenge in the winter. This study investigated the most appropriate greenhouse cladding material and thermal screen configuration for strawberry production in the winter by considering greenhouse air temperature, relative humidity (RH, vapor pressure deficit (VPD, and solar radiation (SR). Two gothic greenhouses with different cladding materials and thermal screen configurations, namely, the single-layer greenhouse and double-layer greenhouse, were used for strawberry cultivation. The greenhouse microclimate was controlled by natural ventilation aided with circulating fans and boilers. Strawberries were planted on 5 greenhouse benches, 660 stands per greenhouse. Daily environmental parameters were recorded and processed into daytime and nighttime. The impacts of cladding material-thermal screen configurations on temperature, RH, VPD, and $\mathrm{SR}$, and the subsequent effect on strawberry yield in both greenhouse systems, were evaluated. Comparing the environmental parameters recorded in the single-layer and double-layer greenhouse showed that VPD and SR were significantly different in the daytime, whereas RH and VPD were significantly different in the nighttime. The post hoc test further showed that RH, VPD, and SR in both greenhouses were significantly different. The significant difference in RH and VPD can be attributed to the inner layer of polyethene in the double-layer greenhouse, which sealed up the pores of the thermal screen, resulting in humidity buildup, causing a lower VPD than in the single-layer greenhouse. The single-layer greenhouse yield was $14 \%$ greater than the double-layer greenhouse yield and can be attributed to the higher daytime VPD and lower RH achieved in the single-layer greenhouse at night. The study established that though the single-layer greenhouse system was cost-effective regarding construction, the operating cost of the single-layer greenhouse was higher than that of the double-layer greenhouse.

Keywords: cultivation; season; microclimate; yield analysis; fresh fruits

\section{Introduction}

A greenhouse is a structure glazed with glass or plastic material and whose environment is controlled for crop production. The greenhouse should maintain temperature, 
relative humidity $(\mathrm{RH})$, carbon dioxide $\left(\mathrm{CO}_{2}\right)$, vapor pressure deficit (VPD), and light levels optimal for crop production [1,2]. Greenhouses enable practices that ensure food safety, better quality, extend the growing season, and allow year-round crop production $[2,3]$. According to Frantz et al. [4], rapid growth and productivity in a controlled environment could be achieved by controlling the root and aerial environment.

Strawberry (Fragaria ananassa) blossoms $35-40$ days after planting and has a short bearing and maturity period of 20-40 days after fertilization. The fleshy strawberry is classified as an aggregate fruit of highly desirable taste, flavor, and rich in vitamins, potassium, fiber, and sugars. Compared to other berries, strawberries have higher percentage compositions of vitamin C, phenolics, and flavonoids. Strawberries are grown in various production systems to produce high-quality fruit yields with sufficient flexibility to meet market demands and labor availability [5]. Strawberries can either be cultivated in the open field (the hill- and matted-row system) or under protection (on benches). Open field crops are mulched either with straw or plastic to aid weed control, conserve soil moisture, control soil temperature, protect roots from cold injury, reduce fruit decay, save irrigation water, and help reduce contamination by keeping the fruit off the soil surface $[6,7]$.

Daytime and nighttime air temperatures between $18{ }^{\circ} \mathrm{C}$ and $24{ }^{\circ} \mathrm{C}$ and $10{ }^{\circ} \mathrm{C}$ and $13{ }^{\circ} \mathrm{C}$, respectively, are required for optimum growth, development, and yield regarding quality and quantity. Jayasekara et al. [1] reported a nighttime temperature in the range of $5-10^{\circ} \mathrm{C}$ using a hot-water heating system (boiler), and a daytime temperature range of $15-25{ }^{\circ} \mathrm{C}$ in an air-inflated double-layer greenhouse (DLGH) and conventional DLGH, and recorded 92.8 and $149.9 \mathrm{~kg}$ strawberry yield, respectively. Ogunlowo et al. [8] reported the lowest minimum and highest maximum temperatures of $2.93^{\circ} \mathrm{C}$ and $3.33^{\circ} \mathrm{C}$ and $29.17^{\circ} \mathrm{C}$ and $29.07^{\circ} \mathrm{C}$ in a conventional SLGH and DLGH with a thermal screen, respectively. Total greenhouse humidity is the summation of the condensation on the covering, ventilation vapor losses, plant transpiration, and soil evaporation. The humidity is expressed as absolute humidity $\left(\mathrm{gm}^{-3}\right)$, specific humidity ( $\mathrm{g}$ water $\mathrm{kg}^{-1}$ air), or $\mathrm{RH}(\%)$. RH is the most commonly used in expressing humidity in the greenhouse micro-atmosphere. The American Society of Agricultural Engineers [9] standards recommend RH in the range of $60-90 \%$ as the most appropriate for greenhouse vegetables, whereas Harel et al. [10] reported that pollination in the greenhouse is significantly enhanced at $60 \% \mathrm{RH}$. Likewise, air RH and daylight integral (DLI) ranges of $60-75 \%$ and $17-20 \mathrm{~mol} \mathrm{~m}^{-2} \mathrm{~d}^{-1}$, respectively, are required for transporting nutrients and effective and efficient metabolic activities.

Another important environmental parameter is VPD. Wang and Lin [11], Li et al. [12], and Akpenpuun et al. [5] reported that exposure to elevated temperatures and VPD could cause physiological, biochemical, anatomical, and morphological changes in plant tissues, affecting the growth and development of different plant organs. According to Shamshiri and Ismail [13], VPD values below $0.2-0.4 \mathrm{kPa}$ result in mineral deficiency symptoms and are favorable to fungal and disease-causing pathogens. They recommended that greenhouse air VPD should be $0.5-1.3 \mathrm{kPa}$ for optimal results in an SLGH for vegetable production. Shamshiri and Ismail [13] and Amani et al. [14], however, reported that $0.8-1.0 \mathrm{kPa}$ VPD is most ideal for optimal plant growth and development in an SLGH and DLGH. Studies on the effect of environmental parameters on the productivity of strawberries are scarce. However, Lieten [15], Khalid et al. [16], and Palencia et al. [17] related the effect of $\mathrm{RH}$ on the performance of greenhouse-grown strawberries, the effect of organic amendments on vegetative growth, fruit, and yield quality, and the yield efficiency of strawberries and its correlation to temperature and solar radiation (SR), respectively. Other researchers have investigated the effect of humidity on vegetables and ornamental plants and reported that high humidity enhanced vegetable growth and that long-term transpiration rate suppression by high humidity could cause local calcium deficiency. Lieten [15] and Jayasekara et al. [1] reported that to achieve maximum yield, a humidity range of $65-75 \%$ is required. Cayli [18] likewise concluded that the thermal uniformity in a double layer greenhouse was superior to a single layer greenhouse and provided better insulation and that using a thermal screen in a single layer greenhouse and double 
layer greenhouse significantly contributed to climatic uniformity. Greenhouse thermal screens have characteristics such as diffusivity, emissivity, and reflectivity, which vary and are dependent on the composition of the materials of manufacture. Greenhouse thermal screens can either be asymmetric or symmetric, and heterogeneous or homogeneous [19]. There are several uses of greenhouse thermal screens, and they include but are not limited to, creating a shade in the summer to reflect solar radiation but allow airflow through them to control temperature and keep the heat inside the greenhouse to save energy during cold periods, thereby preventing temperatures from going below the minimum desired, and control humidity and condensation drip. Greenhouse thermal screens allow the control of light, temperature, and humidity more precisely, which results in better climate control in the greenhouse. By utilizing the right screen, which isolates the greenhouse during cold periods, the heat loss is reduced, which invariably results in fuel conservation and ultimately leads to reduced operational cost [20,21]. Because there is a constant exchange of heat and air between the greenhouse and outside environment, through the wall and roof openings, greenhouse thermal screens serve as an insulation material, therefore creating a barrier to reduce the rate of heat and air exchange during cold periods [20]. This allows the conservation of heat collected during the day, as well as the infrared radiation absorbed by the greenhouse floor, which is released as heat at night. High energy demand due to low ambient temperature results in high energy consumption, which subsequently increases the operational cost of greenhouses in the winter and on cold nights. However, the application of thermal screens in the greenhouse decreases the volume of the air within the greenhouse to be heated, thereby helping to reduce the cost of fuel or the electric energy needed to heat the greenhouse air space. Akpenpuun et al. [5] recorded that using two layers of cladding material in combination with a thermal screen saves energy by about $58.2 \%$. The high operational cost incurred by growers and researchers, especially during the winter, calls for energy management and efficiency in greenhouse cultivation, as heating cost contributes about $40 \%$ of the total cost of greenhouse crop production [22]. Bakar et al. [23] and Rasheed et al. [24] reported that greenhouse design factors and construction materials have significant consequences on the greenhouse energy demand and the annual operational cost.

Strawberry cultivation highly depends on environmental parameters, as such its cultivation in the greenhouse in the winter season is challenging. The objective of this study, therefore, was to investigate the effect of extra cladding material on the productivity of strawberries. To achieve the set objective, (i) the effect of the extra polyethene layer (PE) on the microclimate parameters in the double layer greenhouse and strawberry yield in both greenhouses was determined, and (ii) the cost analysis of the two greenhouse systems was conducted.

\section{Materials and Methods}

\subsection{Experimental Site and Procedure}

The experiment was conducted in winter (3 October 2020-3 April 2021) at the Smart Agriculture Innovation Center, Kyungpook National University, Buk-gu, Daegu, South Korea. Daegu Metropolitan City is on latitude of $35.60^{\circ}$ and longitude of $128.35^{\circ} \mathrm{E}$ and is $\sim 48 \mathrm{~m}$ above mean sea level. The climate of Daegu is humid subtropical.

Two gothic greenhouses used for this experiment were oriented east-west, the best for SR reception in the study area, especially in winter when temperatures are low. The greenhouses were of the same structural specifications but differed in the number of cladding materials configurations. Though the DLGH had two roof vent openings, one of the openings was permanently closed so that the two greenhouses could be compared. The SLGH was glazed with one polyolefin layer and a thermal screen. In contrast, the DLGH was glazed with a layer of polyolefin, thermal screen, and polyethene. Polyethene was chosen as the inner layer to insulate (thermal blanket) the inner surface of the thermal screen to prevent the stored heat from escaping during the night and to prevent humidity transport through the thermal screen. Polyolefin is more expensive than polyethene. The 
greenhouses' dimensions were $24 \times 7 \times 4 \mathrm{~m}$ with a planting area of $18 \times 4.5 \mathrm{~m}$. The total floor area of each greenhouse was $184.8 \mathrm{~m}^{2}$ and the areas of the side and ridge vents were $30 \%$ of the greenhouse floor area with a roof curvature angle of $25.5^{\circ}$. The thickness and SR transmittance of the polyolefin and polyethene films were $150 \mu \mathrm{m}$ and $91 \%$, and $150 \mu \mathrm{m}$ and $88 \%$, respectively, for all SR wavelengths. The thermal screen properties were $3.5 \mathrm{~mm}$, $0.037 \mathrm{Wm}^{-1} \mathrm{~K}^{-1},<0.001 \%, 0.10$, and 0.90 for thickness, thermal conductivity, thermal radiation transmittance, reflectance, and emittance, respectively, for both greenhouses. The thermal screens of both greenhouses and the inner layer of polyethene in the DLGH all opened at 08:30 and closed at 18:00, making both greenhouses a single polyolefin layer greenhouse during the daytime. The roof and side vents automatically opened when the greenhouses' air temperature exceeded $21{ }^{\circ} \mathrm{C}\left(\mathrm{T}_{\text {air }}=21.5^{\circ} \mathrm{C}\right)$ and $23^{\circ} \mathrm{C}\left(\mathrm{T}_{\text {air }}=23.5^{\circ} \mathrm{C}\right)$, respectively, and closed when the air temperature fell below $21^{\circ} \mathrm{C}$. The thermal screen in both greenhouses, however, were retracted (open) to the roof ridge at the specified time interval of 8:00 to 18:00, and closed 18:00 to 8:00 daily, while the polyolefin layer in both greenhouses opened and closed when the air temperature was $23 \pm 0.5^{\circ} \mathrm{C}$ and $21 \pm 0.5^{\circ} \mathrm{C}$, respectively. The second cladding layer (polyethene) in the DLGH remained open from 8:30 to 17:30 and closed between 17:30 and 8:30. An indirect heating system (stand-alone boiler) placed at the corridor to each greenhouse's entrance heated the greenhouse air space on cold days and nights. The boiler used diesel as fuel. Connected to the boiler tanker was a heat pipe installed at the root zone of the plants, circulating hot water through the length of the pipe to raise the root zone and greenhouse air space temperature. The boiler temperature set range was $7.5-8.5^{\circ} \mathrm{C}$ for its activation and deactivation, as $8^{\circ} \mathrm{C}$ is the lowest temperature recommended for strawberry growth and development Bradford et al. [25]. The daytime air temperature range in the literature for optimum strawberry growth and development is between $18{ }^{\circ} \mathrm{C}$ and $24{ }^{\circ} \mathrm{C}$ in all greenhouse types. To aid air circulation and ensure uniform environmental conditions within the greenhouses, four $0.5 \mathrm{hp}, 25 \mathrm{~m}^{3} / \mathrm{min}$ per unit capacity and $25 \mathrm{~cm}$ window-sized air-circulating fans were installed at the height of $1.9 \mathrm{~m}$ from the greenhouse floor in the east and west ends.

The "Seolhyang" variety of strawberry seedlings was transplanted on 3 October 2020, on five greenhouse-raised benches (plot) spaced $60 \mathrm{~cm}$ apart, measuring $76 \times 1500 \mathrm{~cm}$. The greenhouse benches were spaced $25 \mathrm{~cm}$ apart, providing a plant density of 132 per bed and 660 plants per greenhouse, and were placed in the east-west orientation of the greenhouse structures. Both greenhouses were irrigated and fertigated from the same open-loop drip irrigation and fertigation systems. The nutrient solution was prepared in two separate $400 \mathrm{~L}$ capacity water reservoirs. The nutrient solution in reservoir A was a mixture of calcium nitrate tetrahydrate $(3.74 \mathrm{~kg})$, potassium nitrate $(6.04 \mathrm{~kg})$, and chelated iron $(0.43 \mathrm{~kg})$, whereas the nutrient solution in reservoir B was a combination of magnesium sulfate $(1.23 \mathrm{~kg})$, magnesium nitrate $(0.85 \mathrm{~kg})$, ammonium phosphate $(1.14 \mathrm{~kg})$, boric acid $(60 \mathrm{~g})$, manganese sulfate $(37.28 \mathrm{~g})$, zinc sulfate $(3.70 \mathrm{~g})$, copper sulfate $(0.75 \mathrm{~g})$, and sodium molybdate dihydrate $(0.40 \mathrm{~g})$. The irrigation rate was $6.4 \times 10^{-4} \mathrm{~m}^{3} \mathrm{~s}^{-1}$ (0.64 1/s per greenhouse) at an interval of $1 \mathrm{~h} 30 \mathrm{~min}$ five times daily, beginning from 08:30. Each irrigation period lasted for $2 \mathrm{~min} 30 \mathrm{~s}$. Standard cultivating practices adopted by Fernandez et al. [26] were followed. The flower bunny bumblebee (Bombus sp) was introduced in each greenhouse to pollinate the strawberries. Figures 1 and 2 show the SLGH and DLGH. The strawberry fruit started ripening in December 2020 and was continuously harvested twice weekly until the experiment was concluded in April 2021. Berry fruits were weighed per bed and the total yield per greenhouse was recorded. Figures 1-6 show the SLGH, DLGH, SLGH, and DLGH layouts, sensors, fans, and boiler location, irrigation and nutrient systems and experimental greenhouse interior and exterior. 


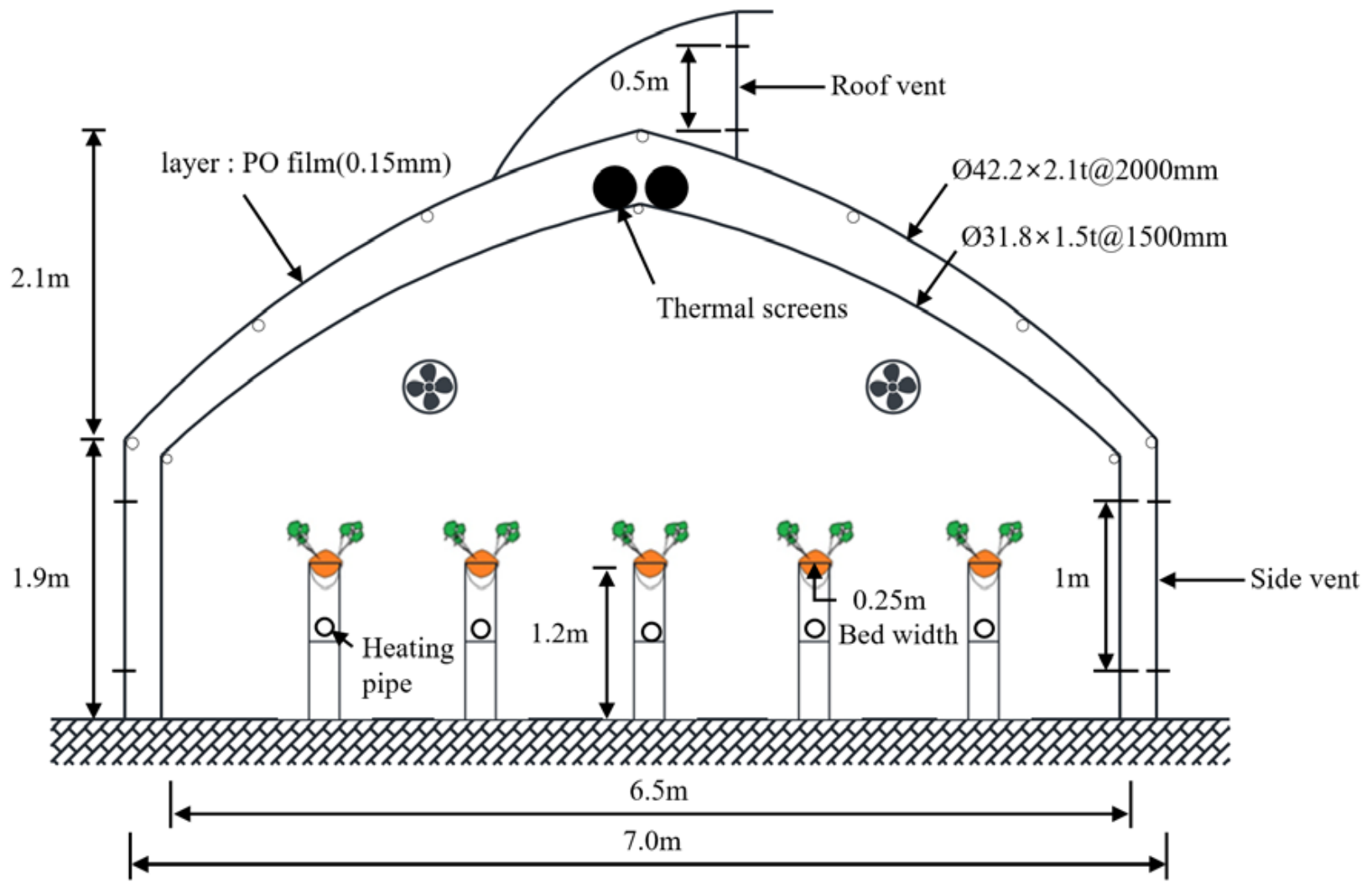

Figure 1. Single-layer greenhouse (SLGH).

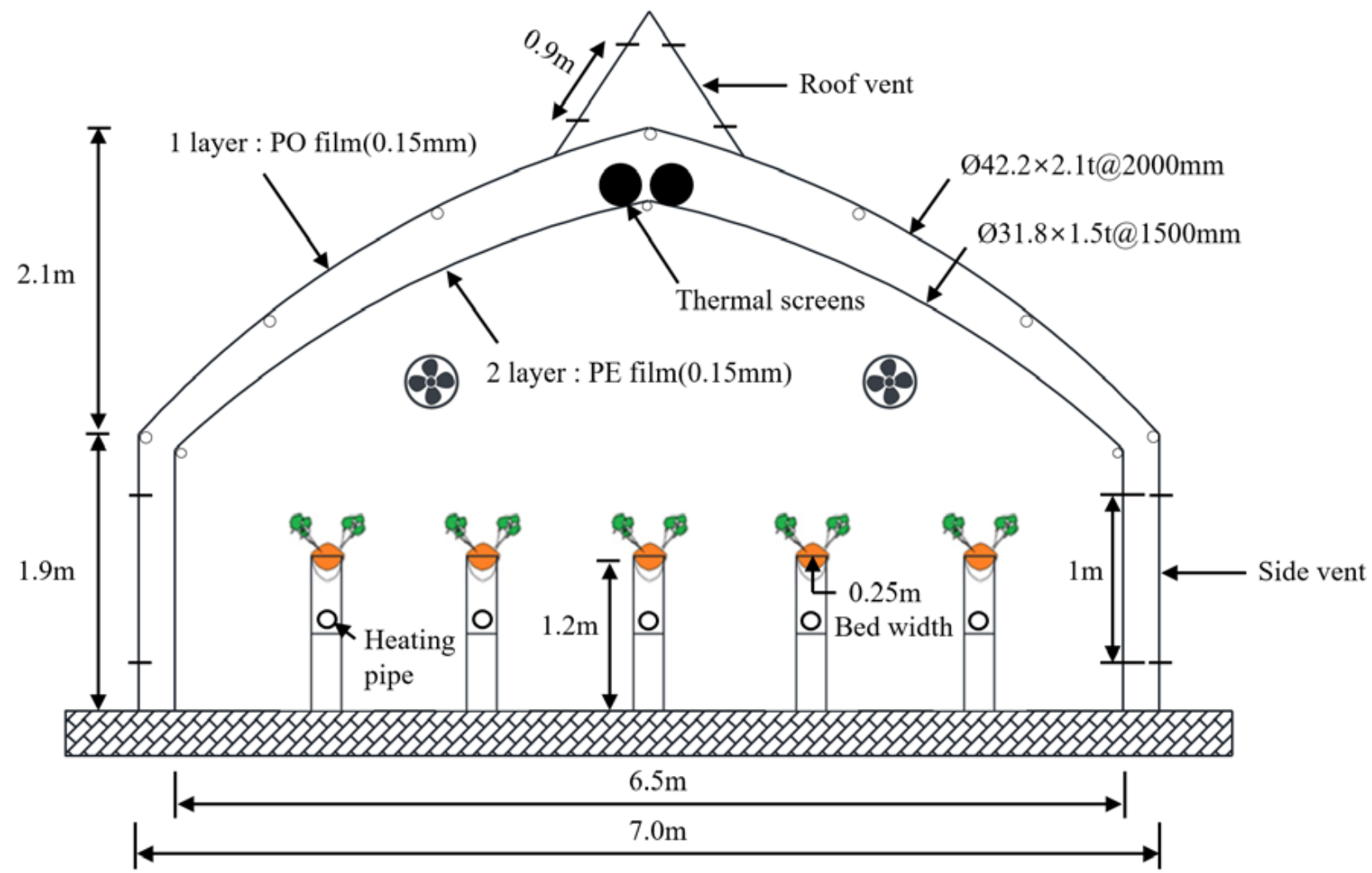

Figure 2. Double-layer greenhouse (DLGH). 


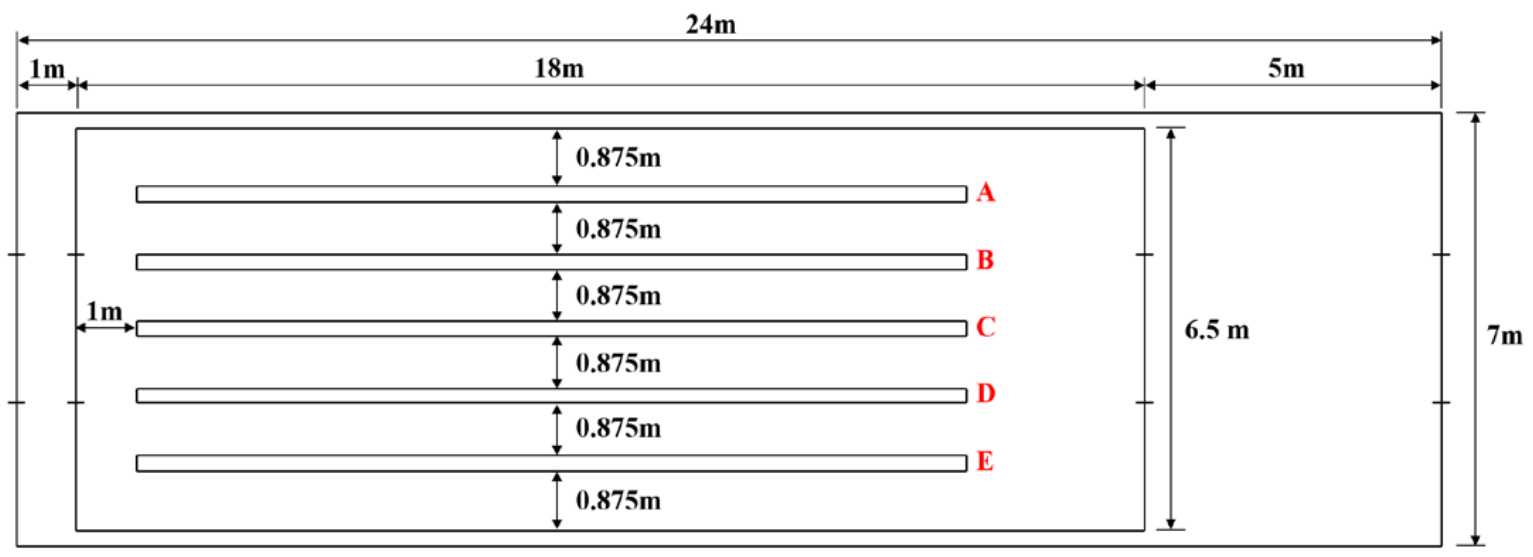

Figure 3. SLGH and DLGH layouts (A, B, C, D, E are greenhouse beds).
$\Delta$ Temperature \& $\mathbf{R H}$ sensor
- Solar radiation sensor
$\approx(80)$ Fan and Direction

\section{South}

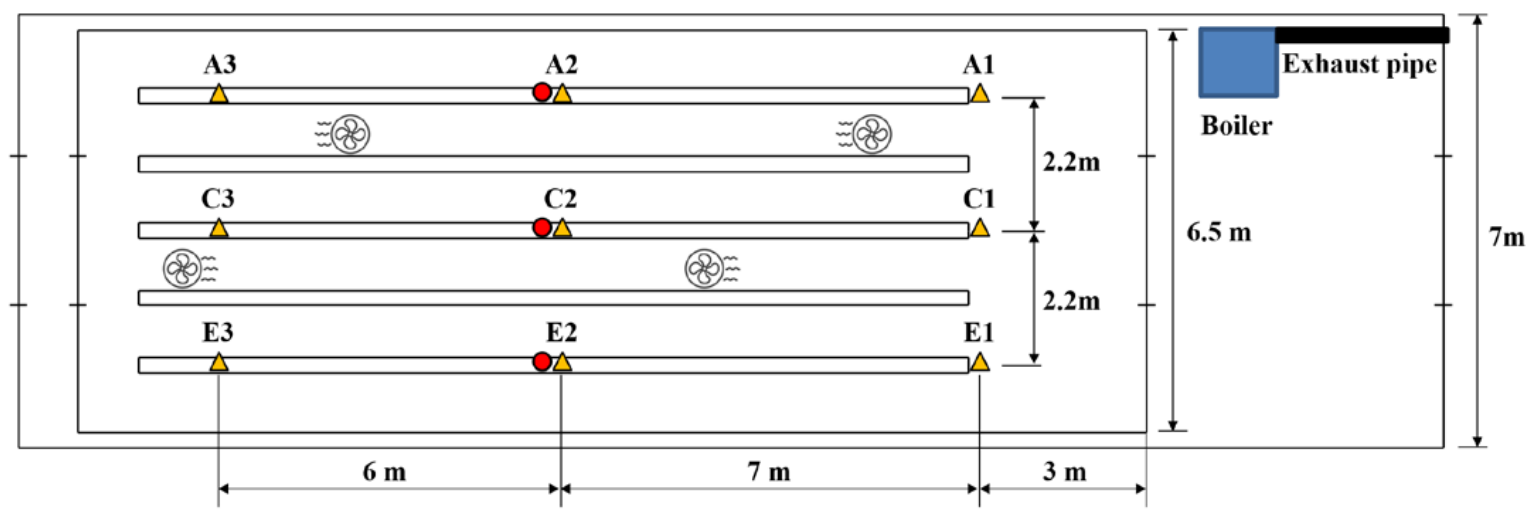

\section{North}

Figure 4. Sensors, fans, and boiler location.

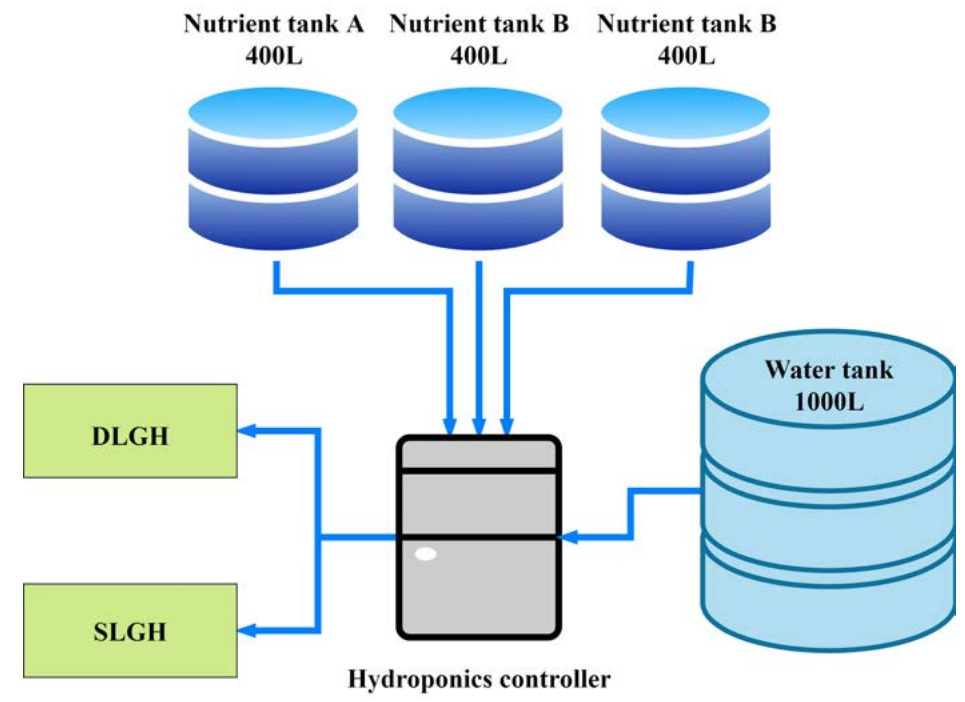

Figure 5. Irrigation and nutrient systems. 
(a)

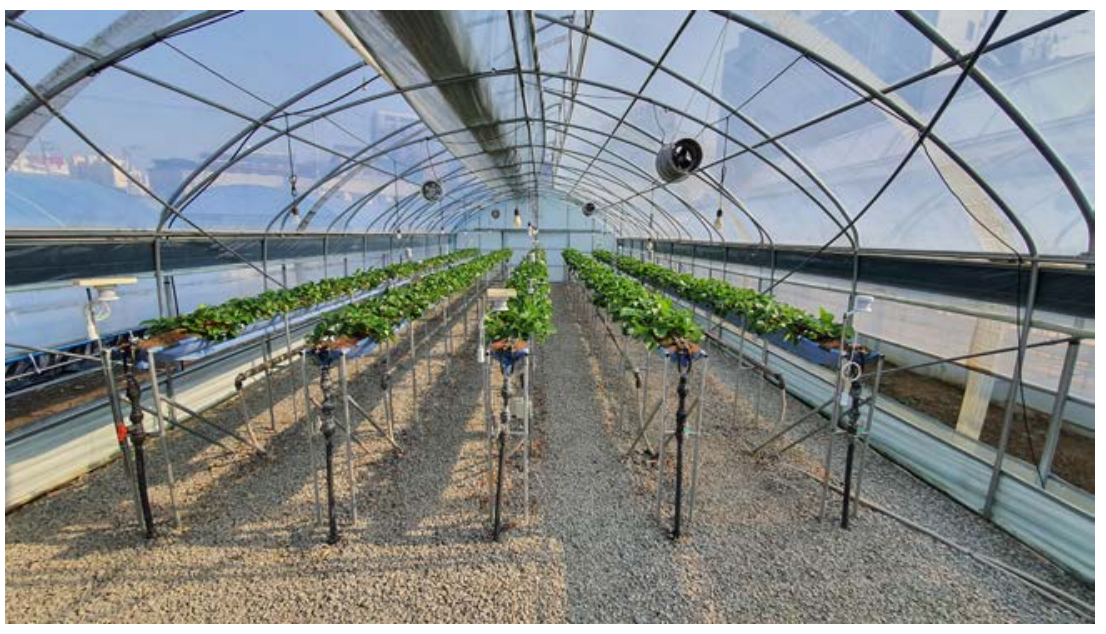

(b)

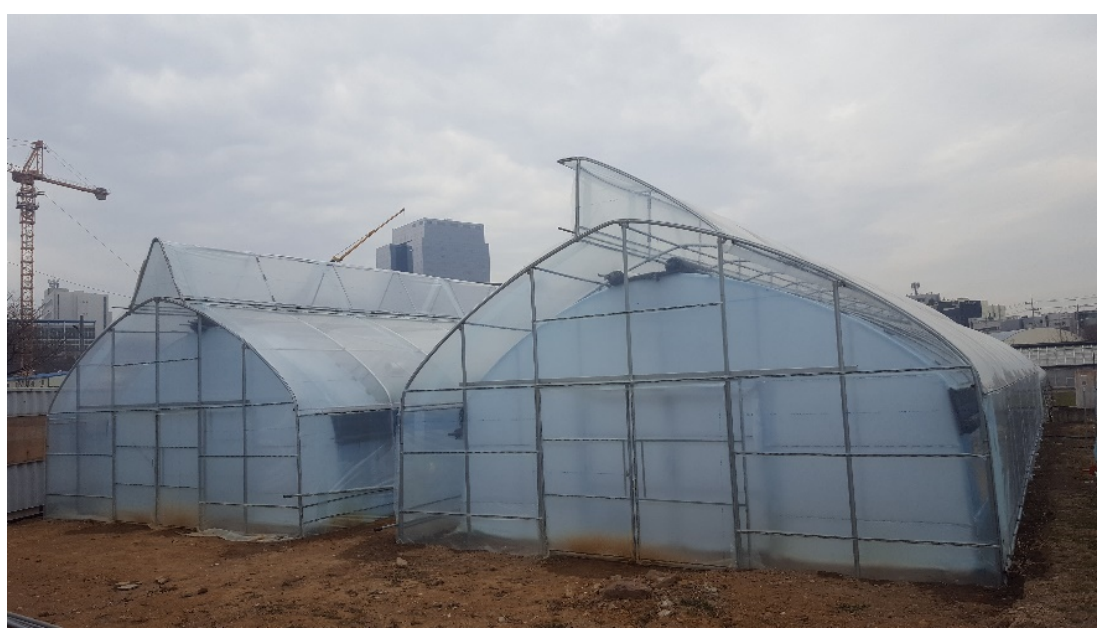

Figure 6. Experimental greenhouses (a) interior and (b) exterior.

\subsection{Instrumentation and Data Collection}

Greenhouse air temperature, RH, and SR were measured continuously. Three air temperature and $\mathrm{RH}$ sensors (accuracy: $\pm 0.25{ }^{\circ} \mathrm{C}, \mathrm{HOBO}$ PRO v2 U23 Pro v2, ONSET, $3 \mathrm{~min}$ in air moving $1 \mathrm{~m} / \mathrm{s} ; 30 \mathrm{~s}$ in stirred water, Onset Computer Corporation, Barnstable, MA, USA) were installed per row (front, middle, and end), $1.54 \mathrm{~m}$ from the greenhouse floor. The SR sensors (accuracy: $\pm 10 \mathrm{~W} / \mathrm{m}^{2}$; response time: $<18 \mathrm{~s}$; nonlinearity: $<1 \%$; spectral range: 300-2800 $\mathrm{nm}$; directional error: $<20 \mathrm{~W} / \mathrm{m}^{2}$; tilt error: $<2 \%$; CMP3 Pyranometer, KIPP \& ZONEN, Delft, The Netherlands) and dataloggers (LR-5042, Kioko, Japan) were placed at the top of the plant canopy to measure the SR from 08:30 to 18:00. All data loggers were programmed to record data every $10 \mathrm{~min}$. The VPD was determined according to the method adopted by Jayasekara et al. [1] and Akpenpuun et al. [5] (Equations (1) and (2)). Harvested berry fruits from each greenhouse were weighed using a digital weighing balance to evaluate yield per bench and total yield per greenhouse.

$$
\begin{gathered}
\mathrm{P}_{\mathrm{s}}=610.78 \times \exp \left(\left(\frac{\mathrm{T}}{\mathrm{T}+238.3}\right) \times 17.27\right), \\
\mathrm{VPD}, \mathrm{kPa}=\frac{\left(1-\left(\frac{\mathrm{RH}}{100}\right)\right) \times \mathrm{P}_{\mathrm{s}}}{1000},
\end{gathered}
$$

where Ps is the saturation vapor pressure $(\mathrm{Pa}), \mathrm{T}$ is the greenhouse air temperature $\left({ }^{\circ} \mathrm{C}\right)$, and $\mathrm{RH}$ is the relative humidity (\%). 


\subsection{Statistical and Sensitivity Analysis}

Data were separated into daytime (08:30-18:00) and nighttime (19:00-08:30) and subjected to descriptive and inferential statistical techniques (analysis of variance and correlation analysis) to determine the yield response to environmental parameters within the greenhouses using Stata version 15.0 (StataCorp LLC, College Station, TX, USA).

\section{Results}

Tables 1 and 2 present the descriptive statistics of the daytime and nighttime environmental data collected in both greenhouses. The daytime descriptive statistics showed that the differences observed between the SLGH and DLGH in temperature, RH, VPD, and SR were $0.2,2.0,0.07$, and 8.98 , respectively, with the DLGH having higher values than the SLGH. In the nighttime, the descriptive statistics showed that the differences observed between the SLGH and DLGH in temperature and RH were 0.03 and 6.33, respectively, with the DLGH having higher values than the SLGH. VPD in the SLGH was, however, higher than in the DLGH by 0.03 .

Table 1. Descriptive statistics of daytime data for single-layer greenhouse (SLGH) and double-layer greenhouse (DLGH).

\begin{tabular}{|c|c|c|c|c|c|}
\hline Parameters & Mean & Standard Deviation & Minimum & Maximum & Range \\
\hline \multicolumn{6}{|c|}{ SLGH } \\
\hline Temperature, ${ }^{\circ} \mathrm{C}$ & 15.70 & 2.50 & 9.27 & 21.78 & 12.51 \\
\hline Relative Humidity (RH), \% & 64.13 & 10.71 & 46.60 & 91.74 & 45.14 \\
\hline Vapor Pressure Deficit (VPD), kPa & 0.76 & 0.29 & 0.16 & 1.53 & 1.37 \\
\hline Solar Radiation (SR), W/m² & ** 151.94 & 101.76 & 8.71 & 549.83 & 541.12 \\
\hline \multicolumn{6}{|c|}{ DLGH } \\
\hline Temperature, ${ }^{\circ} \mathrm{C}$ & 15.92 & 2.46 & 9.21 & 21.70 & 12.50 \\
\hline $\mathrm{RH}, \%$ & 66.13 & 10.28 & 46.56 & 93.47 & 46.92 \\
\hline $\mathrm{VPD}, \mathrm{kPa}$ & 0.83 & 0.28 & 0.22 & 1.58 & 1.35 \\
\hline $\mathrm{SR}, \mathrm{W} / \mathrm{m}^{2}$ & ** 160.92 & 111.47 & 3.24 & 631.57 & 628.33 \\
\hline
\end{tabular}

** statistically significant, $\alpha=0.05$.

Table 2. Descriptive statistics of night data for SLGH and DLGH.

\begin{tabular}{|c|c|c|c|c|c|}
\hline Parameters & Mean & Standard Deviation & Minimum & Maximum & Range \\
\hline \multicolumn{6}{|c|}{ SLGH } \\
\hline Temperature, ${ }^{\circ} \mathrm{C}$ & 10.21 & 2.33 & 8.08 & 19.56 & 11.48 \\
\hline RH, \% & $* * 87.48$ & 3.96 & 73.80 & 94.59 & 20.78 \\
\hline $\mathrm{VPD}, \mathrm{kPa}$ & $* * 0.23$ & 0.05 & 0.14 & 0.40 & 0.26 \\
\hline \multicolumn{6}{|c|}{ DLGH } \\
\hline Temperature, ${ }^{\circ} \mathrm{C}$ & 10.24 & 2.48 & 5.82 & 19.33 & 13.48 \\
\hline RH, \% & $* * 93.81$ & 2.16 & 85.52 & 97.98 & 12.45 \\
\hline $\mathrm{VPD}, \mathrm{kPa}$ & $* * 0.21$ & 0.04 & 0.12 & 0.37 & 0.25 \\
\hline
\end{tabular}

The mean daytime and nighttime temperatures in the SLGH were $15.72{ }^{\circ} \mathrm{C} \pm 2.52{ }^{\circ} \mathrm{C}$ and $10.20^{\circ} \mathrm{C} \pm 2.32{ }^{\circ} \mathrm{C}$, respectively, whereas $15.92^{\circ} \mathrm{C} \pm 2.52{ }^{\circ} \mathrm{C}$ and $10.28^{\circ} \mathrm{C} \pm 2.44{ }^{\circ} \mathrm{C}$ were achieved in the DLGH, respectively. The daytime minimum and maximum temperatures were in the same range of $9-23{ }^{\circ} \mathrm{C}$, which was the temperature setpoint range for the roof and side vent-opening control system. The daytime and nighttime descriptive statistics also showed that the greenhouses were identical in temperature, RH, and VPD, except for SR, which was higher in the DLGH. Figures 7 and 8 show the trend of the mean daytime and nighttime temperature fluctuations in SLGH and DLGH, respectively. 


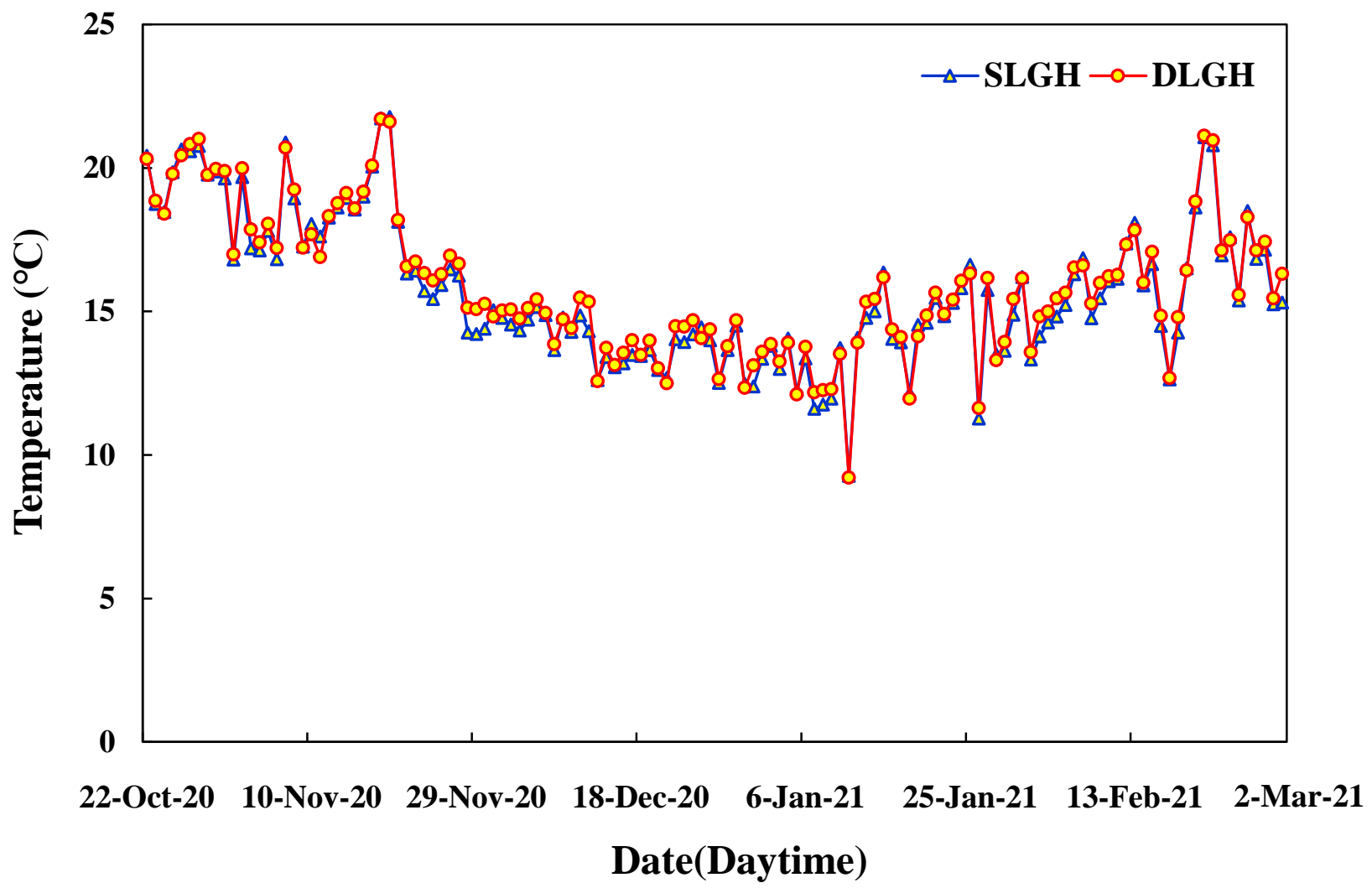

Figure 7. The trend of mean daytime temperature fluctuations in SLGH and DLGH.

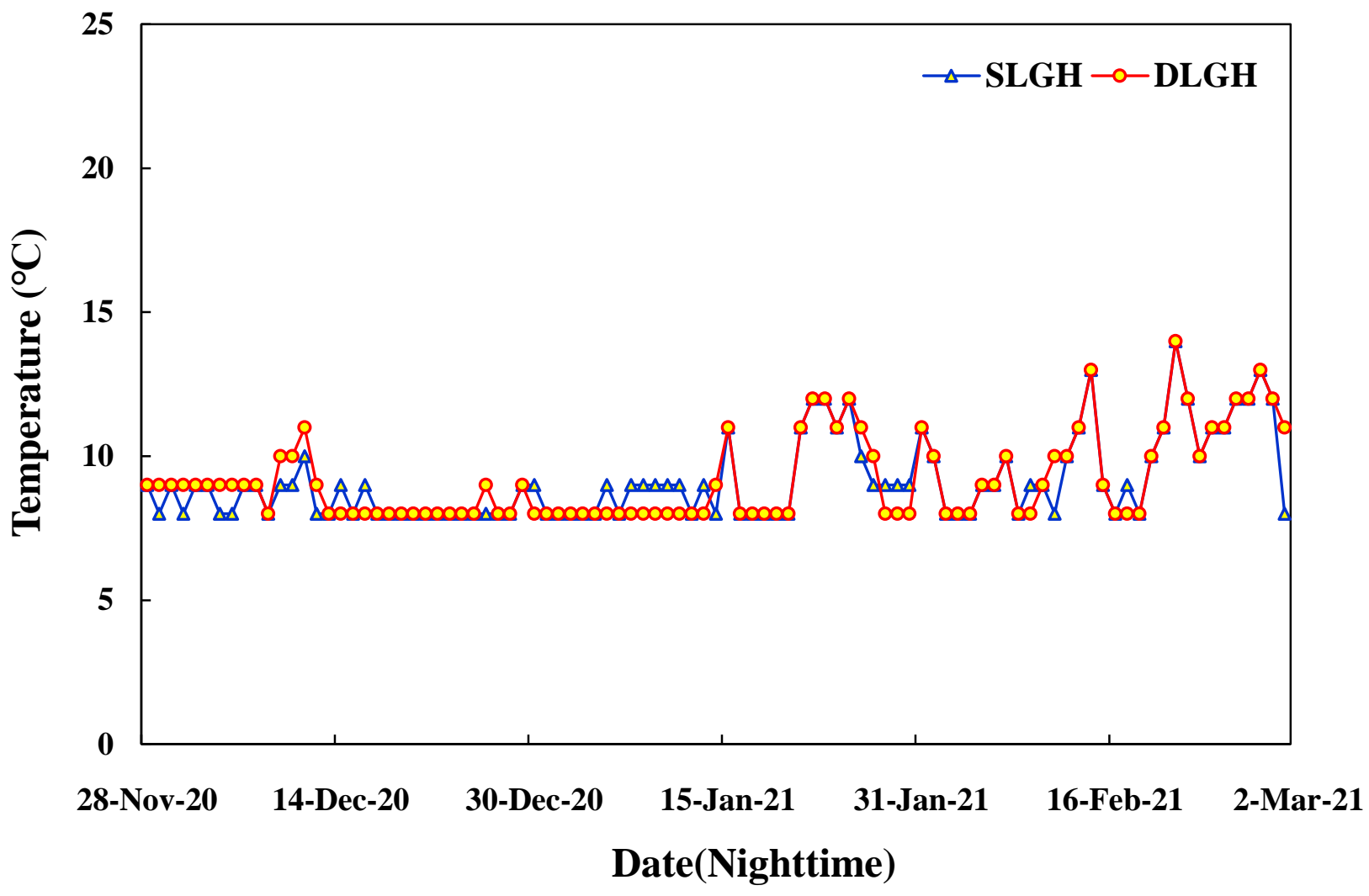

Figure 8. The trend of mean nighttime temperature fluctuations in SLGH and DLGH. 
The mean daytime RH recorded in the SLGH and DLGH was similar, except that the mean nighttime $\mathrm{RH}$ was $87.48 \% \pm 3.96 \%$ and $93.81 \% \pm 2.16 \%$, respectively. A difference in the RH means values of $2.00 \%$ and $6.33 \%$ was recorded during the daytime and nighttime, respectively. The daytime RH ranges recorded in SLGH and DLGH were 46.60-91.74\% and $46.56-93.47 \%$, whereas the nighttime ranges were $73.80-94.59 \%$ and $85.52-97.98 \%$, respectively. Figures 9 and 10 show the mean daily daytime and nighttime RH fluctuations in SLGH and DLGH.

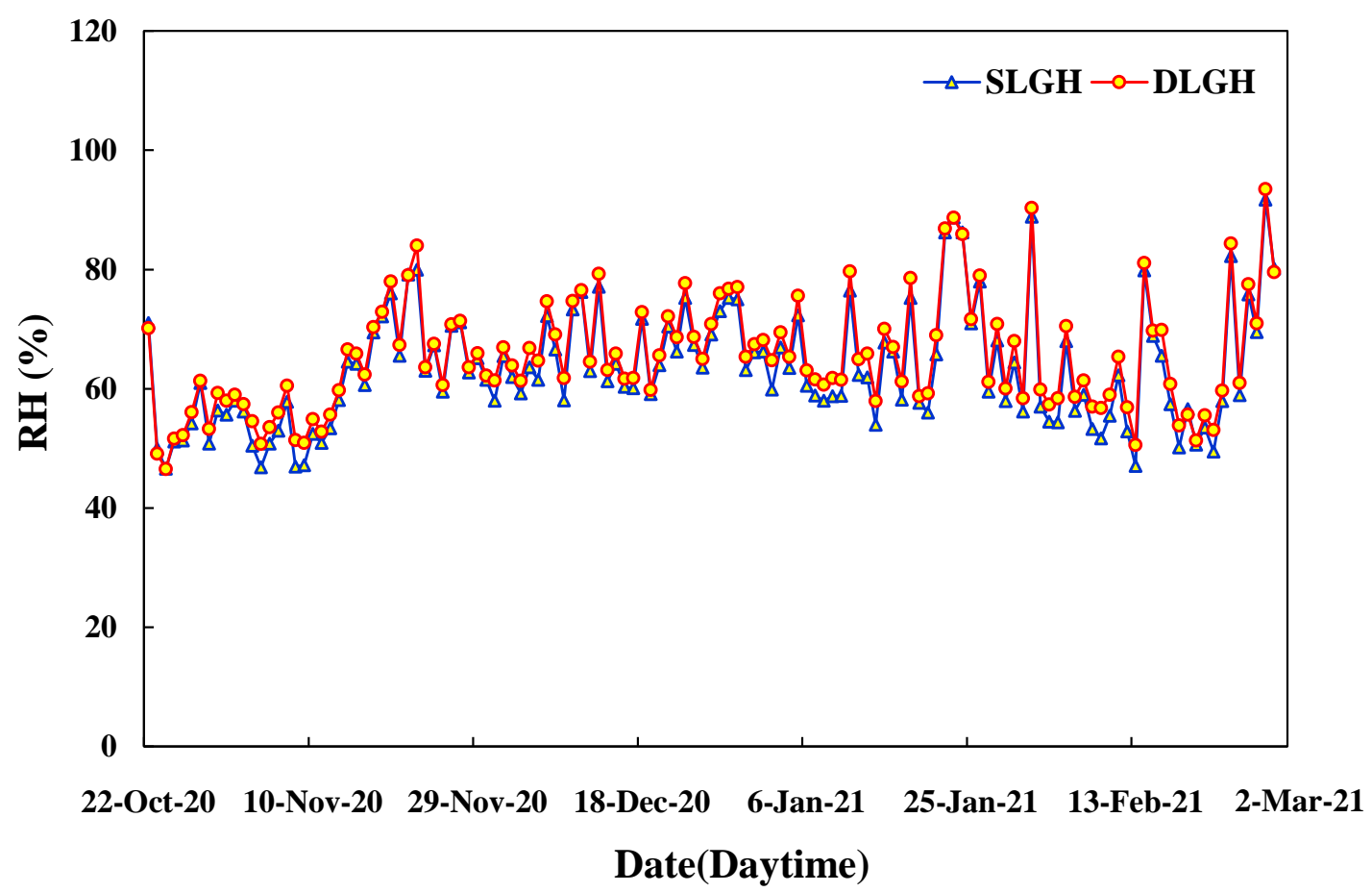

Figure 9. The trend of mean daily daytime RH fluctuations in SLGH and DLGH.

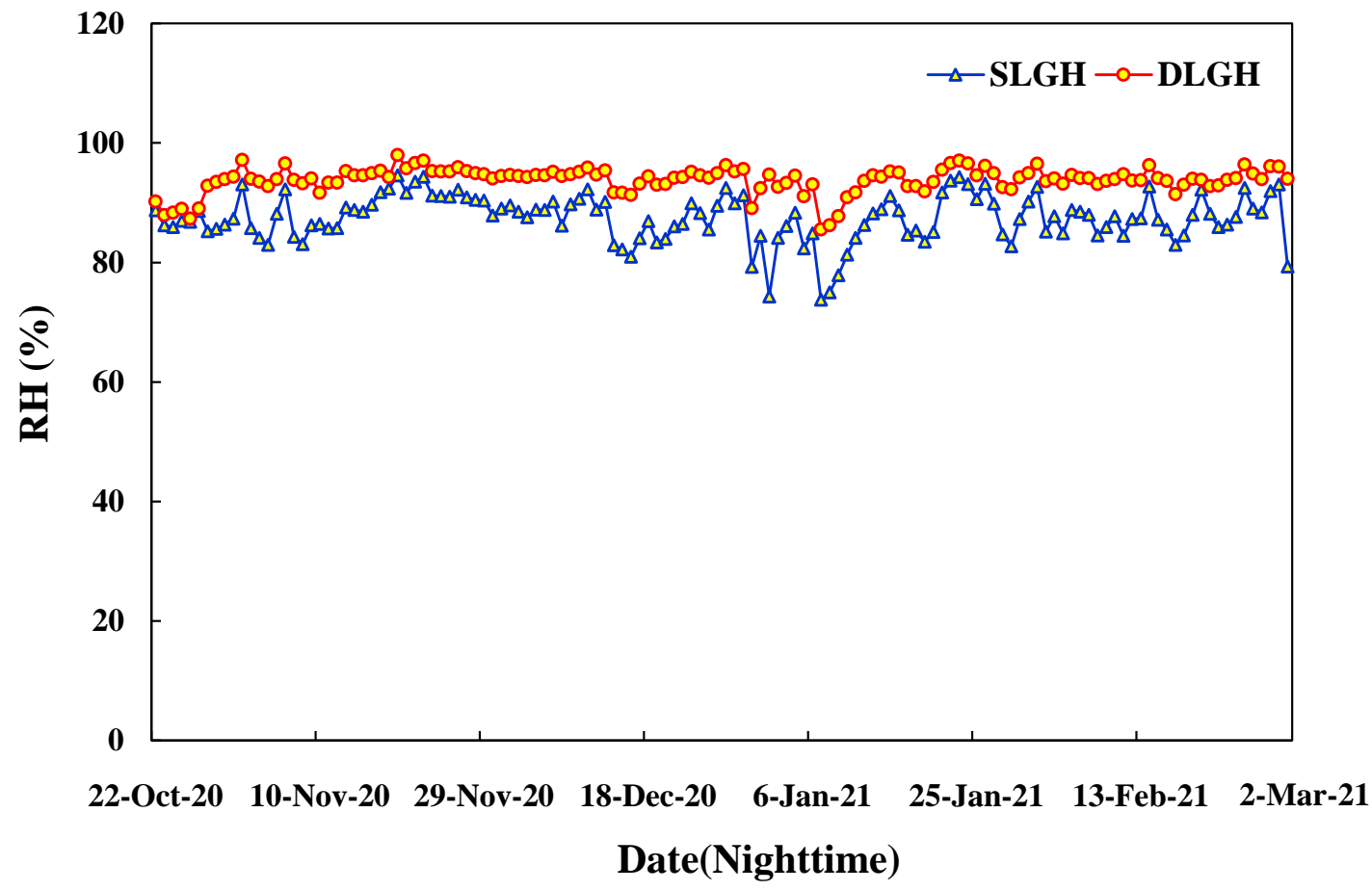

Figure 10. The trend of mean daily nighttime RH fluctuations in SLGH and DLGH. 
The mean daytime and nighttime VPD of 0.76 and $0.23 \mathrm{kPa}$ were recorded, respectively, in the SLGH. In the DLGH, the mean daytime and nighttime VPD of 0.83 and $0.21 \mathrm{kPa}$ were recorded, respectively. Figures 11 and 12 show the mean daily daytime and nighttime VPD recorded in both greenhouses.

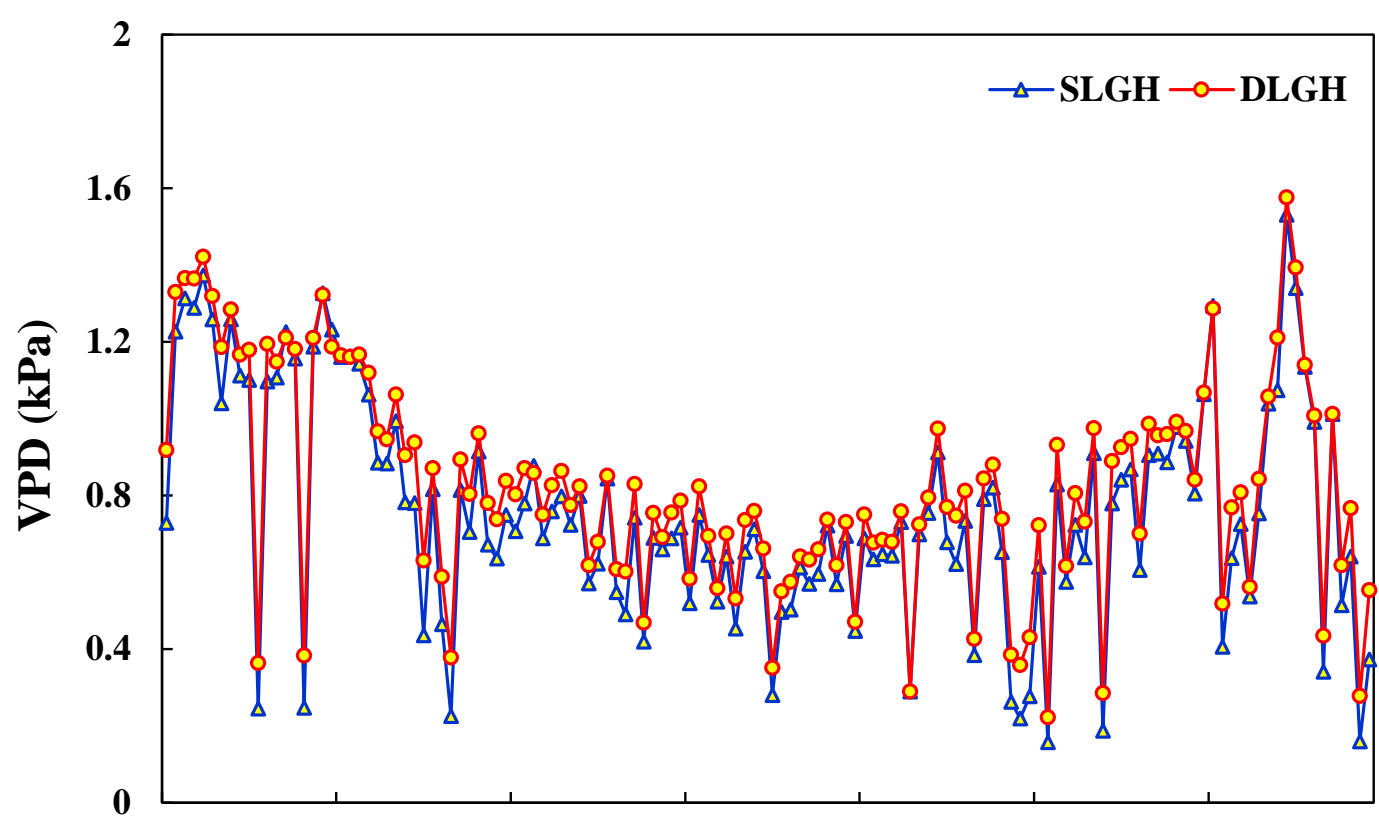

22-Oct-20 10-Nov-20 29-Nov-20 18-Dec-20 6-Jan-21 25-Jan-21 13-Feb-21 2-Mar-21

Date(Daytime)

Figure 11. The trend of mean daytime vapor pressure deficit (VPD) in SLGH and DLGH.

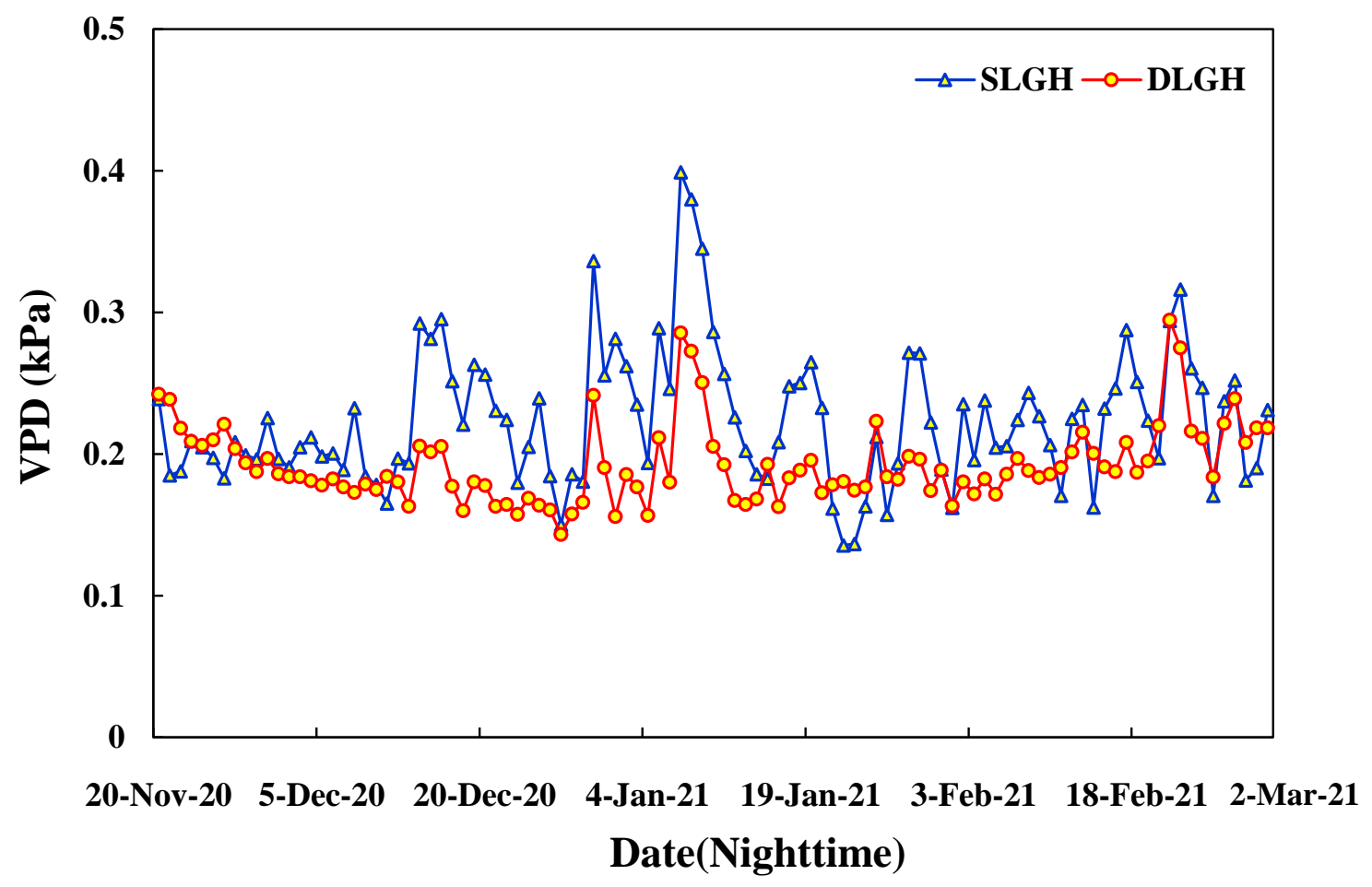

Figure 12. The trend of mean nighttime VPD in SLGH and DLGH. 
The range of SR received in SLGH and DLGH was $8.71-549.83 \mathrm{Wm}^{-2}$ and 3.24-631.57 $\mathrm{Wm}^{-2}$, respectively. The second layer of polyethene and thermal screen retracted during the daytime, making the DLGH function as an SLGH, receiving 5.6\% more SR than the SLGH due to greater exposure to incident sun rays because of obstructions caused by the buildings on the DLGH's side. This resulted in a significant difference in the radiation available within both greenhouses. The SR deficit can be attributed to obstructions around the experimental site and the thermal screen that retracted into the greenhouse roof ridge, obstructing sunrays. Figures 13-16 show the SR distribution patterns in the SLGH and DLGH and their ambient environment on a cloudy and sunny day, respectively.

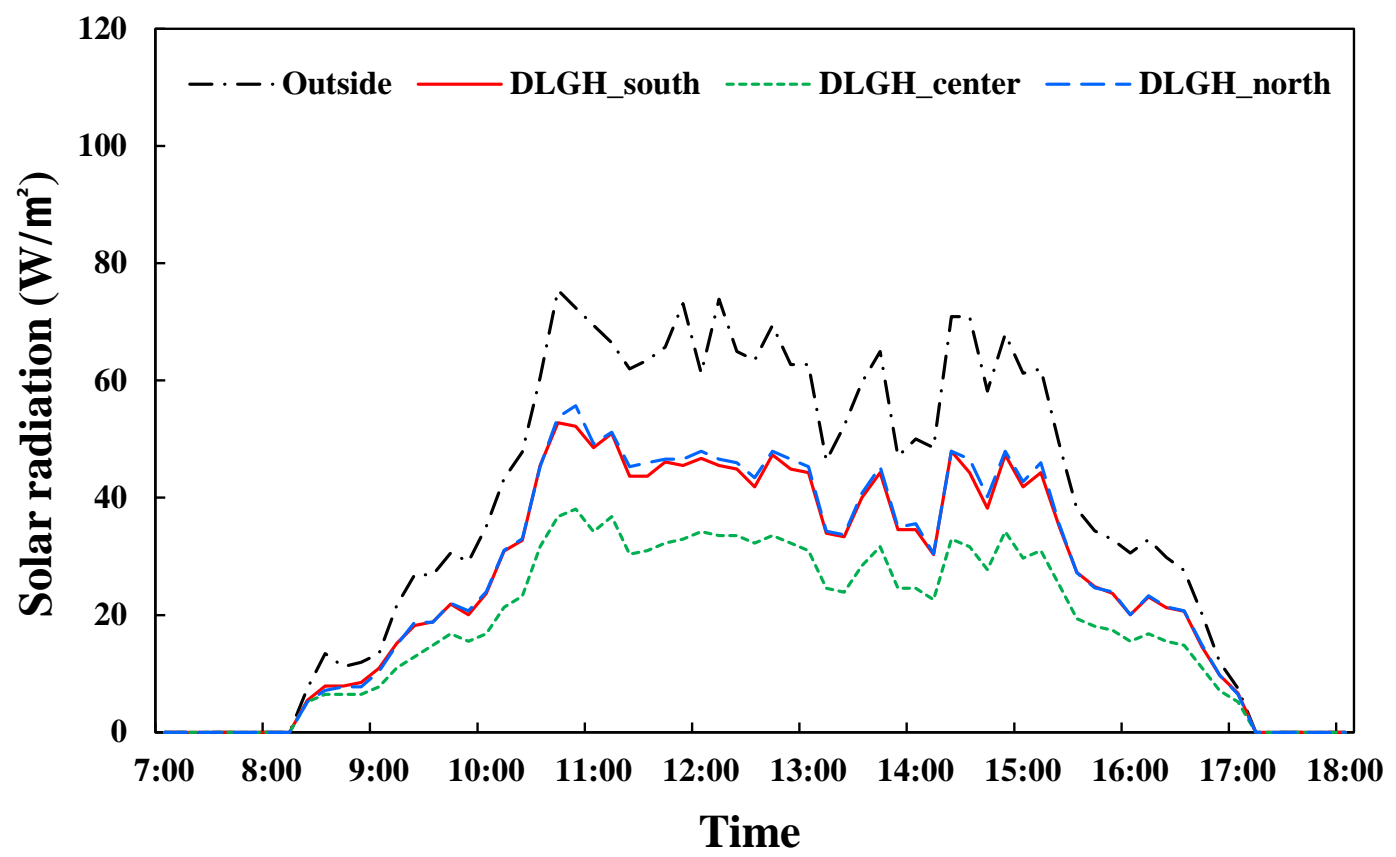

Figure 13. SR pattern in the SLGH and ambient environment on a cloudy day.

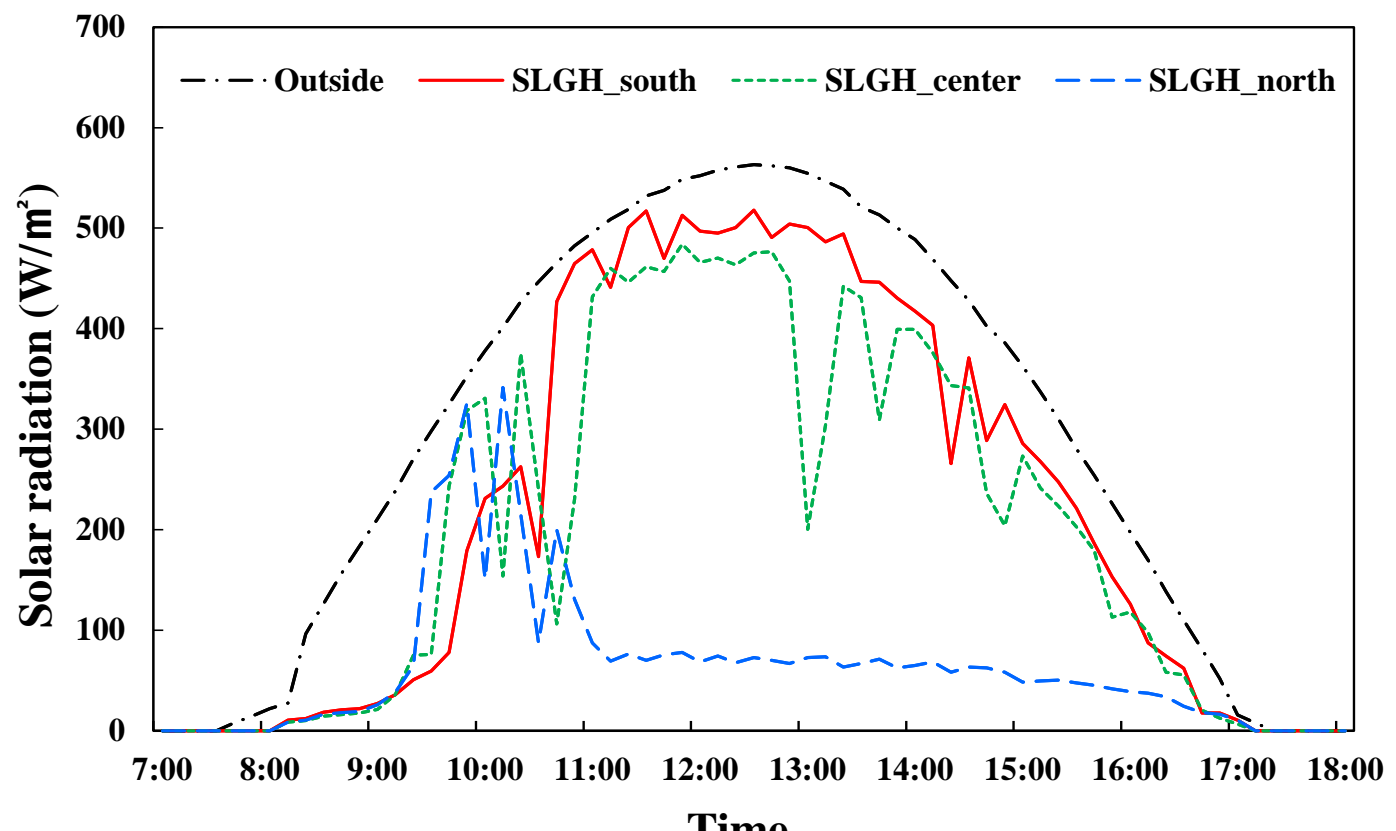

Figure 14. SR pattern in the SLGH and ambient environment on a sunny day. 


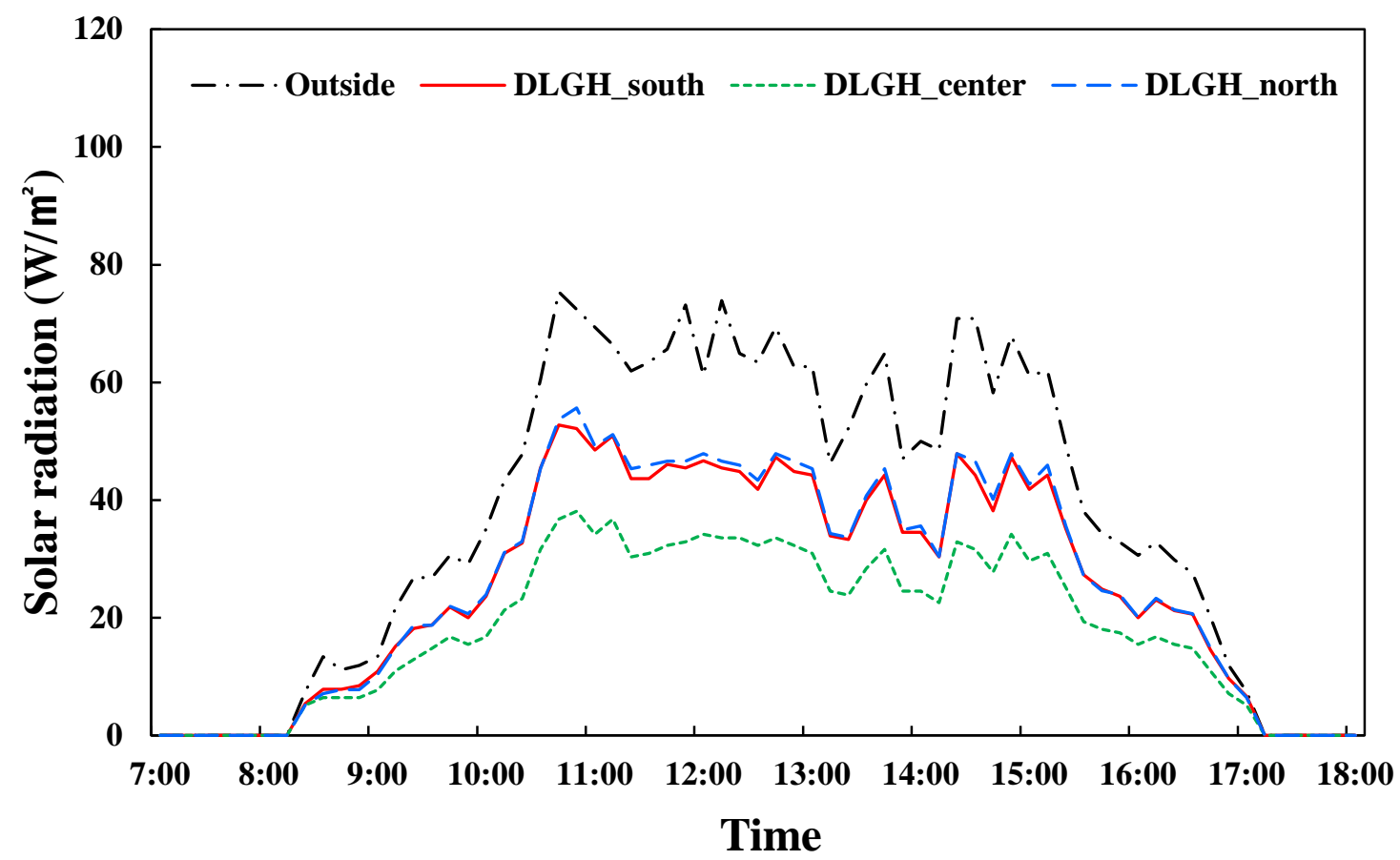

Figure 15. SR pattern in the DLGH and ambient environment on a cloudy day.

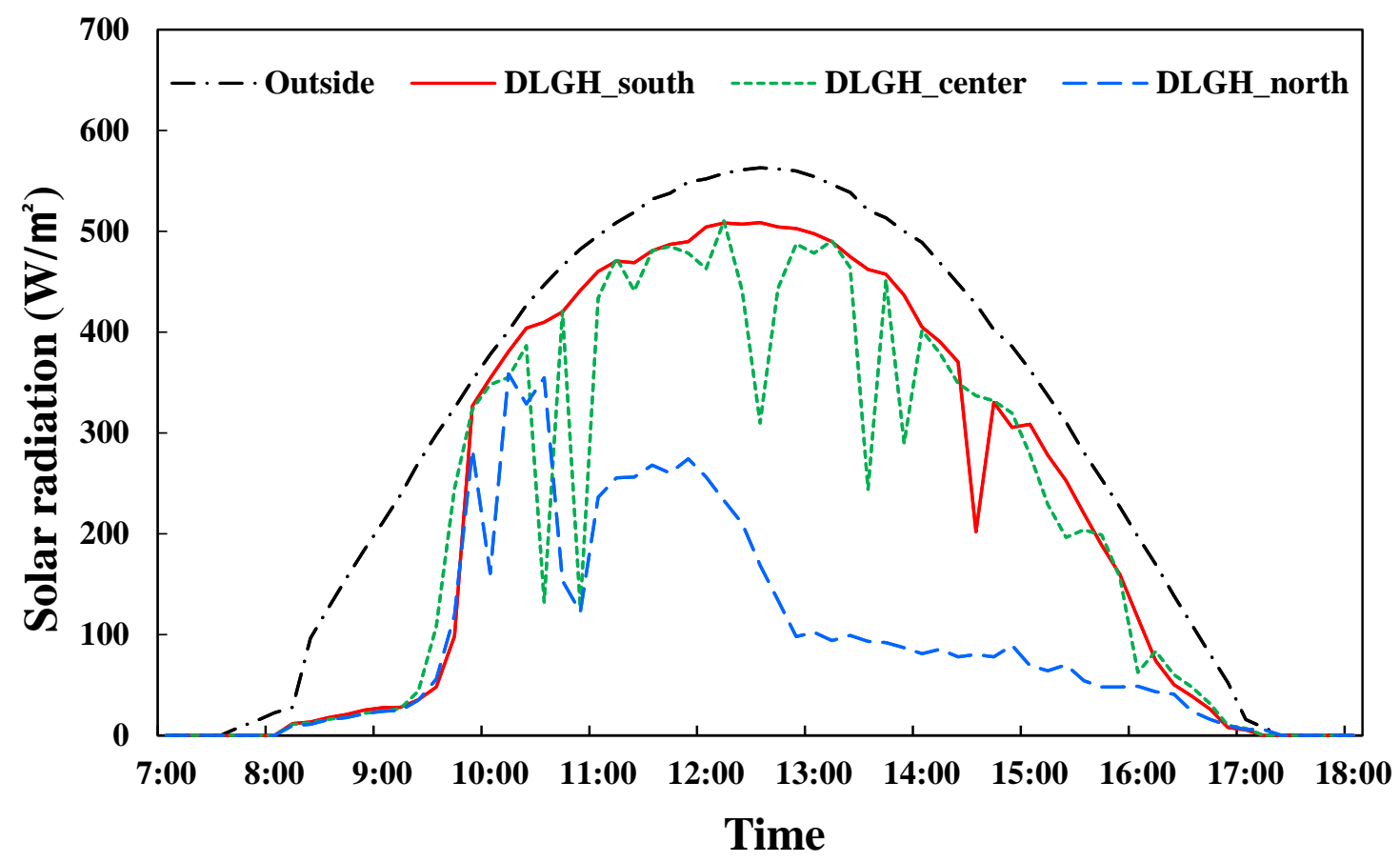

Figure 16. SR pattern in the DLGH and ambient environment on a sunny day.

\section{Discussion}

The day and night temperature ranges recorded in this experiment were within $20.5^{\circ} \mathrm{C}$ and $27.4^{\circ} \mathrm{C}$, reported by Tang et al. [27] as the optimum daytime temperature for SLGH strawberry production. Kim [28] and Jayasekara et al. [1] reported daytime and nighttime temperatures of $15^{\circ} \mathrm{C}-25^{\circ} \mathrm{C}$ and $5{ }^{\circ} \mathrm{C}-10^{\circ} \mathrm{C}$, respectively. However, Bradford et al. [25] reported that the photoperiod-insensitive temperature range of Honeoye, $\mathrm{RH} 30$, and Tribute strawberry varieties varied from $14{ }^{\circ} \mathrm{C}$ to $26^{\circ} \mathrm{C}$. Cayli [18] reported daytime and nighttime temperature ranges of $12.18{ }^{\circ} \mathrm{C}-12.53{ }^{\circ} \mathrm{C}$ and $9.96^{\circ} \mathrm{C}-10.83^{\circ} \mathrm{C}$ in an SLGH with 
thermal screen and heating at night. Cayli [18] further reported daytime and nighttime temperatures $17.08^{\circ} \mathrm{C}-17.49^{\circ} \mathrm{C}$ and $14.17^{\circ} \mathrm{C}-14.64^{\circ} \mathrm{C}$ in a DLGH with thermal screen and heating at night. Kacira [29] and Rouphaela [30] reported that a daily thermal periodicity difference of $5{ }^{\circ} \mathrm{C}-7^{\circ} \mathrm{C}$ is required for optimal physiological functioning and metabolic activities. Kittas et al. [31] reported that an air temperature range of $30^{\circ} \mathrm{C}-35^{\circ} \mathrm{C}$ is necessary for optimal greenhouse crop production, whereas Sabir and Singh [32] and Gruda [2] reported that the optimal daytime and nighttime air temperatures of $21^{\circ} \mathrm{C}-29.5^{\circ} \mathrm{C}$ and $18.5^{\circ} \mathrm{C}-21{ }^{\circ} \mathrm{C}$ are required for most greenhouse vegetables biomass allocation. There was no significant difference between the SLGH and DLGH's daytime and nighttime temperatures $(\alpha=0.01)$.

The $\mathrm{RH}$ range recorded in the SLGH and DLGH were both within the range reported by Jayasekara et al. [1] of $50-100 \%$ and $40-85 \%$ in an air-inflated and conventional DLGH, respectively. Kroggel and Kubota [33] recommended a maximum nighttime RH of 95\% and an optimum daytime RH of $40-60 \%$ to avoid tip burn. Kittas et al. [31], Katsoulas and Kittas [34], and Shamshiri et al. [35] reported that plants exposed to high temperatures require high RH to neutralize heat stress. However, prolonged exposure to excessive $\mathrm{RH}$ is detrimental to growth and development. Lieten [15] also reported an optimum RH level of $65-75 \%$ during the day for good growth, development, and yield of strawberries in the greenhouse, whereas Jayasekara et al. [1] reported $85 \%$ in a conventional DLGH, heavily saturated at night, but recorded $\mathrm{RH}$ as low as $40 \%$ during the daytime. High humidity, especially during the day, could cause tip burn and cat-faced strawberries. Cayli [18] reported daytime and nighttime humidity as $70.57-73.85 \%$ and $84.95-86.28 \%$ in an SLGH, and $70.17-72.34 \%$ and $84.68-86.71 \%$ in a DLGH, both with a thermal screen and heating at night. The higher RH recorded in the DLGH during the nighttime resulted from less air leakage and preventing humidity transport to the ambient environment due to the inner layer of polyethene.

The daytime VPD in both greenhouses were within the range reported by Rosales et al. [36], but below 0.8-1.0 kPa, and $0.9 \mathrm{kPa}$ and $1.6 \mathrm{kPa}$ reported by Shamshiri et al. [35] and Kroggel and Kubota [33], respectively. However, Quinn et al. [37] reported VPD ranges of 2.5-4.5 kPa and 1.5-2.0 kPa in a non-VPD controlled and VPD controlled polyolefin-filmcovered SLGH, respectively. Rosales et al. [36] and Speetjens et al. [38] reported that VPD values between $0.2 \mathrm{kPa}$ and $1.0 \mathrm{kPa}$ are recommended for pollination and prevention of fungal diseases, while Iraqi et al. [39] and Katsoulas and Kittas [34] recommended optimal day and night VPDs of $0.8 \mathrm{kPa}$ for an optimal photosynthetic rate that would result in optimal SLGH crop yield.

The lower VPD $(0.21 \mathrm{kPa})$ recorded in the DLGH resulted in a higher condensation level than in the SLGH, reflecting VPD as a derivative of RH in the RH readings recorded in the DLGH. Additionally, the lower the VPD, the higher the potential of vapor condensing in the greenhouse microclimate, resulting in rot. According to Zolnier et al. [40], VPD estimation is the determining factor in evaluating the condensation potential of a greenhouse environment, directly affecting the productivity of plants.

SR reception levels in the greenhouses depended on the clarity of the clouds, as the maximum SR recorded in the SLGH, DLGH, and ambient environment were 549.83, 631.6, and $783.1 \mathrm{Wm}^{-2}$, respectively, on a sunny day. However, on a cloudy day, the maximum SR received in the SLGH, DLGH, and outside the greenhouses were 78.6 and $110.4 \mathrm{Wm}^{-2}$, respectively. The total SR received throughout the experimental period was 605.3, 641.4, and $1281.4 \mathrm{MJm}^{-2}$, respectively in the SLGH, DLGH, and outside the greenhouse. The total SR was converted to DLI using the method described by Ting and Giacomelli [41]. The total daylight integral (DLI) was, therefore, $6.9,7.4$, and $14.8 \mathrm{~mol} \mathrm{~m}^{-2} \mathrm{~d}^{-1}$ in the SLGH, DLGH, and outside, respectively. Yoshida et al. [42] reported that although strawberries require high light intensity, they do reasonably well in a light intensity range as low as 8.64-25.9 $\mathrm{mol} \mathrm{m}^{-2} \mathrm{~d}^{-1}\left(100-300 \mu \mathrm{mol} \mathrm{m}^{-2} \mathrm{~s}^{-1}\right)$. The DLI recorded in the SLGH and DLGH was less than the lowest DLI reported by Yoshida et al. [42]. DLI of $12-19 \mathrm{~mol} \mathrm{~m}^{-2} \mathrm{~d}^{-1}$ and $20-25 \mathrm{~mol} \mathrm{~m}^{-2} \mathrm{~d}^{-1}$ are the minima for optimum greenhouse productivity [43]. Faust et al. [44], 
however, reported SR values of 5-10 mol m ${ }^{-2} \mathrm{~d}^{-1}, 10-20 \mathrm{~mol} \mathrm{~m}^{-2} \mathrm{~d}^{-1}, 20-30 \mathrm{~mol} \mathrm{~m}^{-2} \mathrm{~d}^{-1}$ and $>30 \mathrm{~mol} \mathrm{~m}^{-2} \mathrm{~d}^{-1}\left(18.9-37.9,37.9-75.7,75.7-113.5\right.$, and $\left.>113.5 \mathrm{Wm}^{-2}\right)$ for low, medium, high, and very-high light crops, respectively. From the classification by Faust et al. [44], the "Seolhyang" variety of strawberries is a low-light crop, which means that the "Seolhyang" variety of strawberries can grow and develop even under light of low intensity.

Though the greenhouses were identical in air temperature, RH, and VPD, their VPD distribution within the greenhouse microclimate was significantly different. The Pareto charts (Figures 17 and 18) show that the nighttime VPD distribution in the SLGH was such that VPD of $0.20-0.40 \mathrm{kPa}$ was $73.7 \%$ of the total VPD readings, whereas readings of $0.0-0.19 \mathrm{kPa}$ were $27.3 \%$. In the DLGH, VPD of $0.2-0.4 \mathrm{kPa}$ was $33.3 \%$, whereas VPD of $0.0-0.19$ was $66.7 \%$ of the total VPD readings recorded. Therefore, the VPD distribution was different in both greenhouses. This is supported by Zhao et al. [45], who reported vertical air temperature and $\mathrm{RH}$ gradient in a naturally ventilated greenhouse, whereas Ogunlowo et al. [8] reported significant variations in the horizontal distribution of air temperature, RH, SR, and VPD within single-layered, double-layered, and multi-span greenhouses. The recommended VPD range for optimum crop production in the greenhouse is $0.20-0.40 \mathrm{kPa}$. The summation of the VPD readings shows that the percentage of VPD readings in the recommended range was more in the SLGH than in the DLGH by $40.4 \%$. Figures 17 and 18 show no significant difference in the daytime VPD distribution between the greenhouses, whereas Figures 19 and 20 show a significant difference in the VPD distribution.

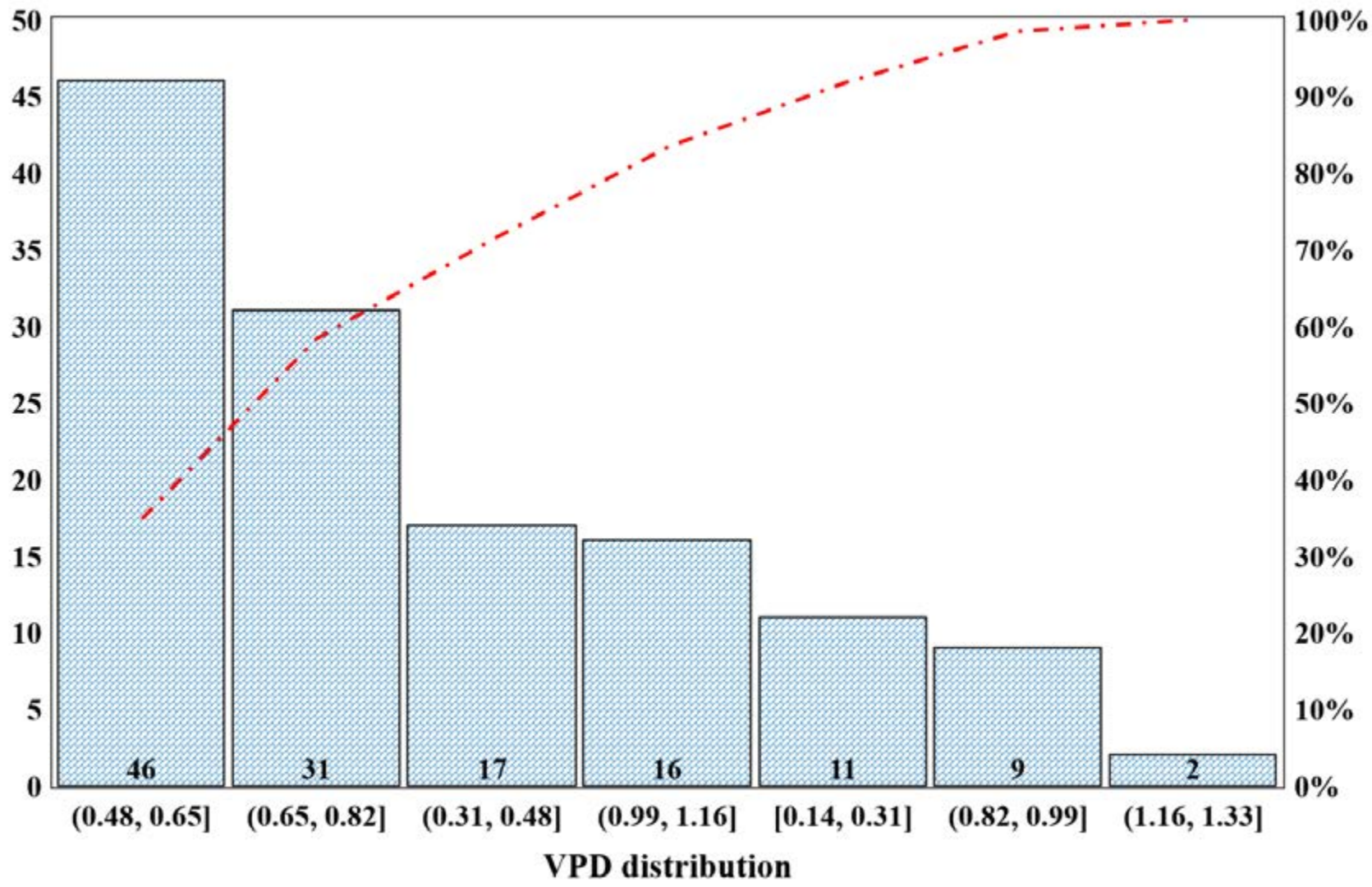

Figure 17. Daytime VPD distribution within SLGH. 


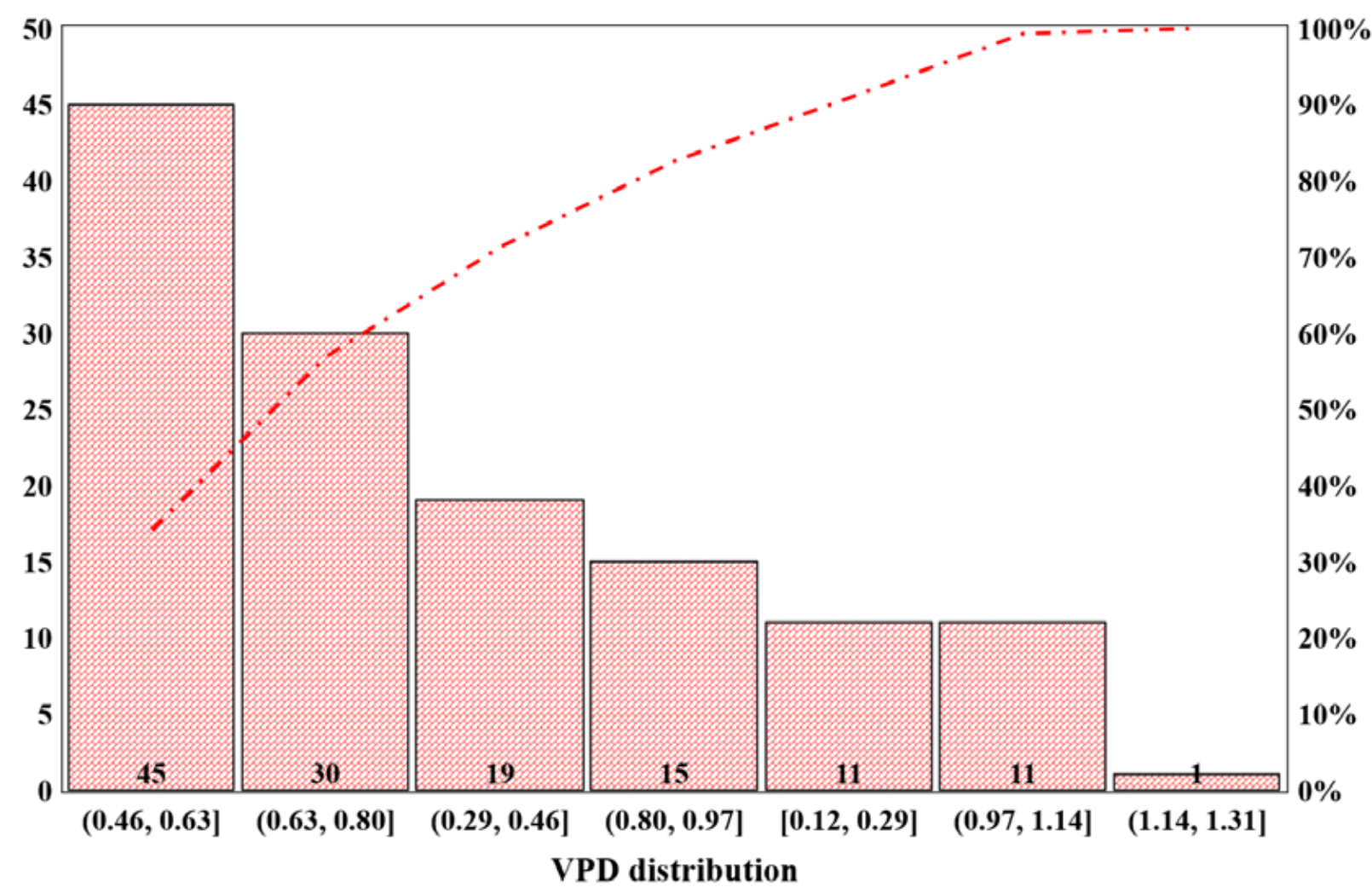

Figure 18. Daytime VPD distribution within DLGH.

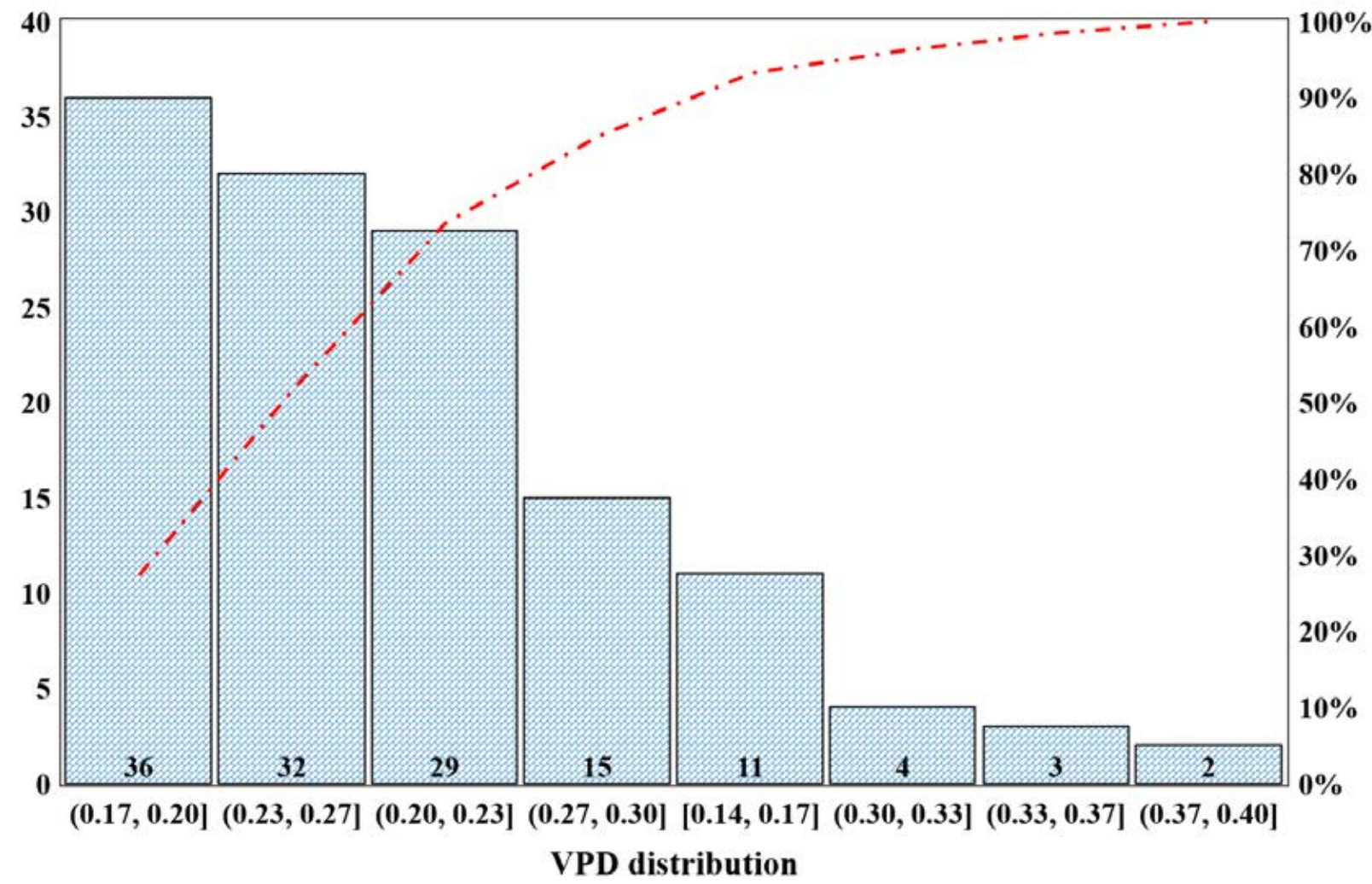

Figure 19. Nighttime VPD distribution within SLGH. 


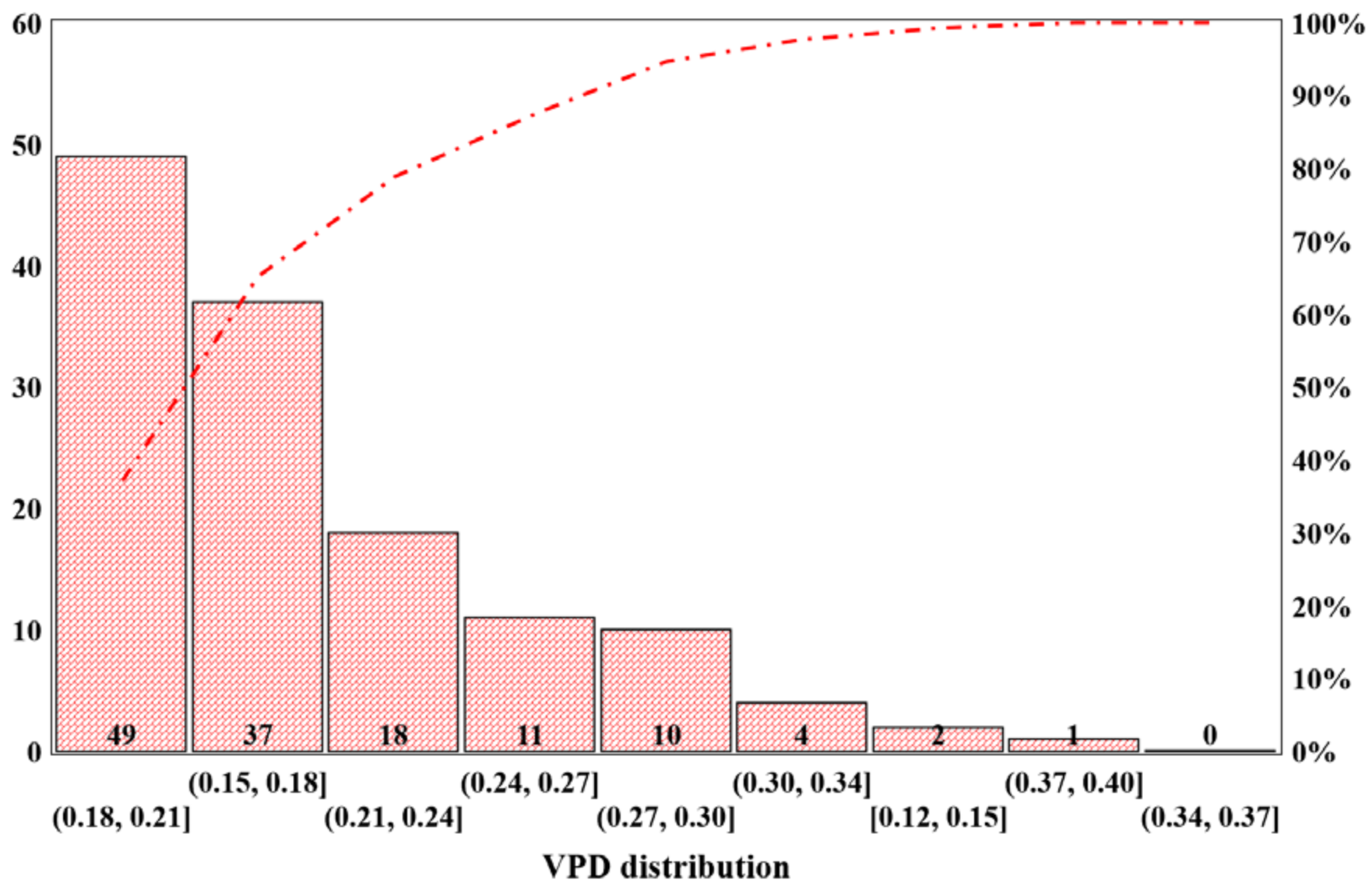

Figure 20. Nighttime VPD distribution within DLGH.

Figures 21-23 show the monthly berry, greenhouse bed, and total marketable yield obtained in the SLGH and DLGH, respectively. The daily yield was sorted, and fruits with weights of 25-65 g were classified as the marketable yield, cumulated, and presented as the monthly yield (Figure 21). Figures 21 and 22 show that the yields in both greenhouses followed the same pattern. The SLGH and DLGH had the highest yield of $45 \mathrm{~kg}$ and $38 \mathrm{~kg}$, respectively, in February 2021, and the most negligible yield of $1.6 \mathrm{~kg}$ and $5.1 \mathrm{~kg}$ in December 2020. The row of crops on the east side of the greenhouses received maximum radiation and had higher yields than those less exposed to SR because the greenhouses and greenhouse beds were oriented in the same east-west direction, resulting in shadowcasting on opposite rows (Figure 22). This subsequently resulted in retarded growth, less development, and low yield from the affected rows. Akpenpuun and Mijinyawa [46] recommended east-west and north-south orientations for maximum SR reception and distribution within a greenhouse and total crop exposure. The total yield and mean yield in kilogramme was 198 and 170, and $19.0 \pm 21.7$ and $15.6 \pm 21.0$ in the the SLGH and DLGH systems, respectively. The total marketable yield in grammes per mole of DLI was 28.3 and 22.9 in the SLGH and DLGH, respectively. The yield obtained in SLGH was 14\% higher than the yield obtained in DLGH. Table 3 shows the descriptive statistics of marketable yield obtained in SLGH and DLGH. 


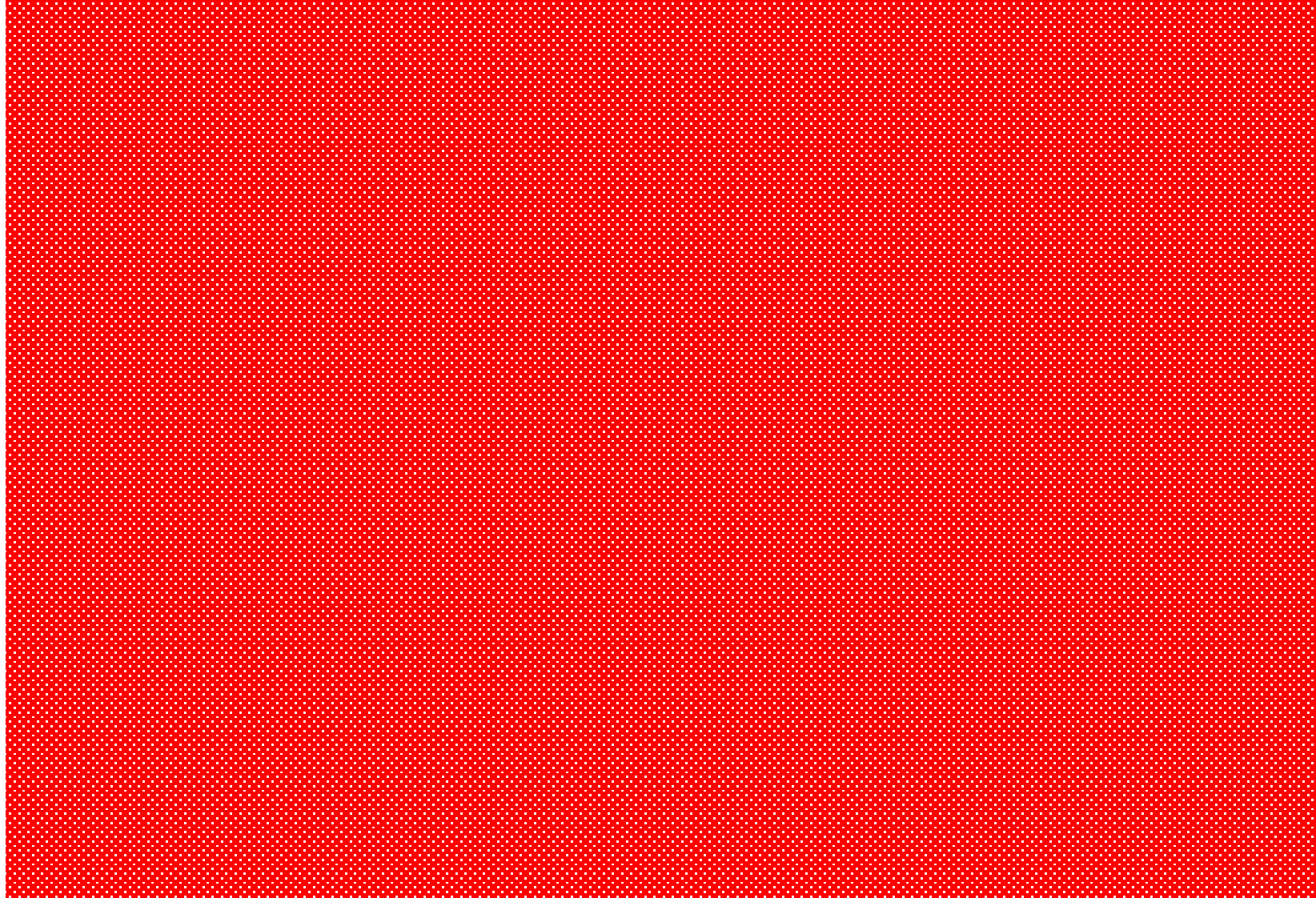

Figure 21. Monthly berry yield.

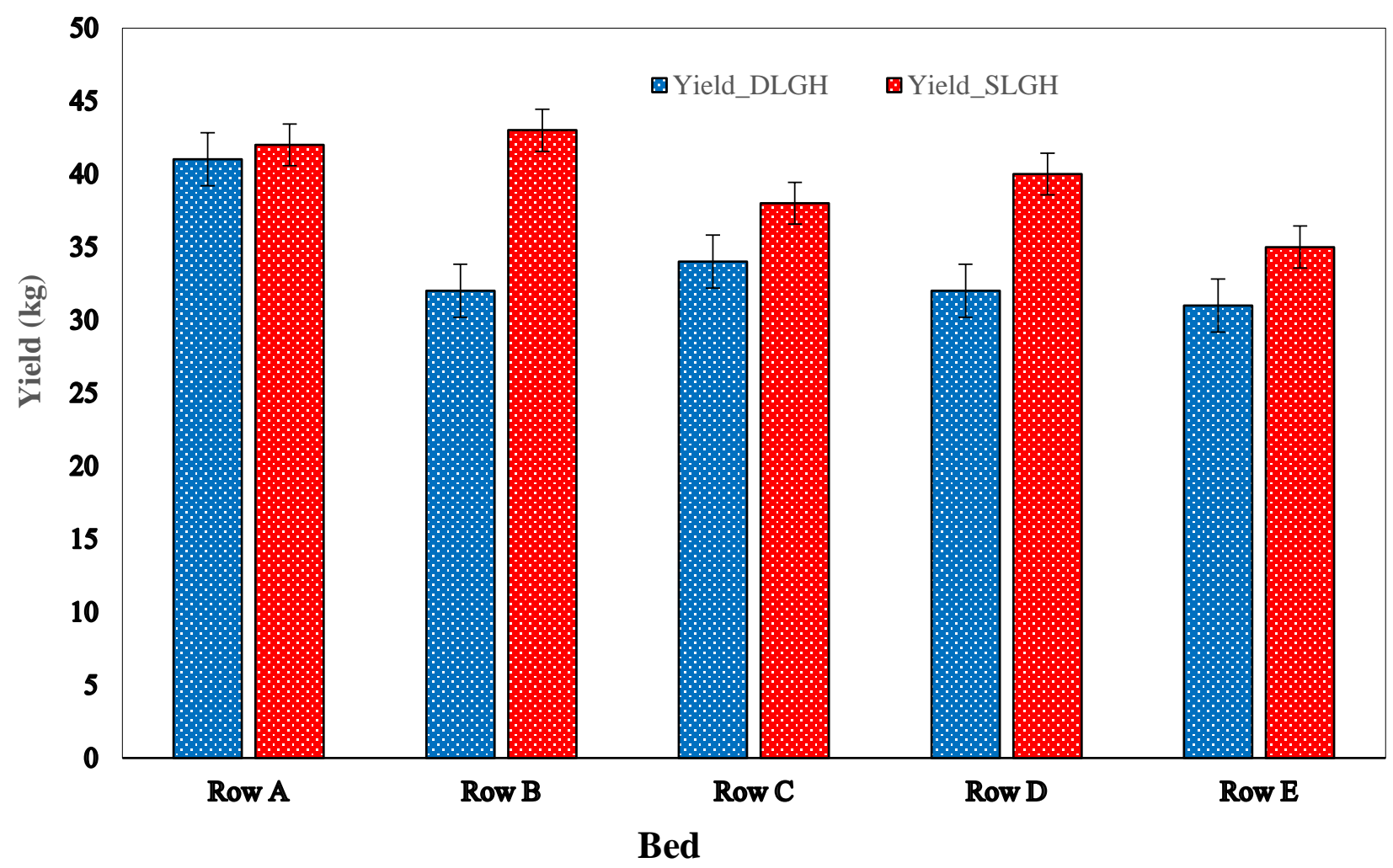

Figure 22. Strawberry yield per bed. 


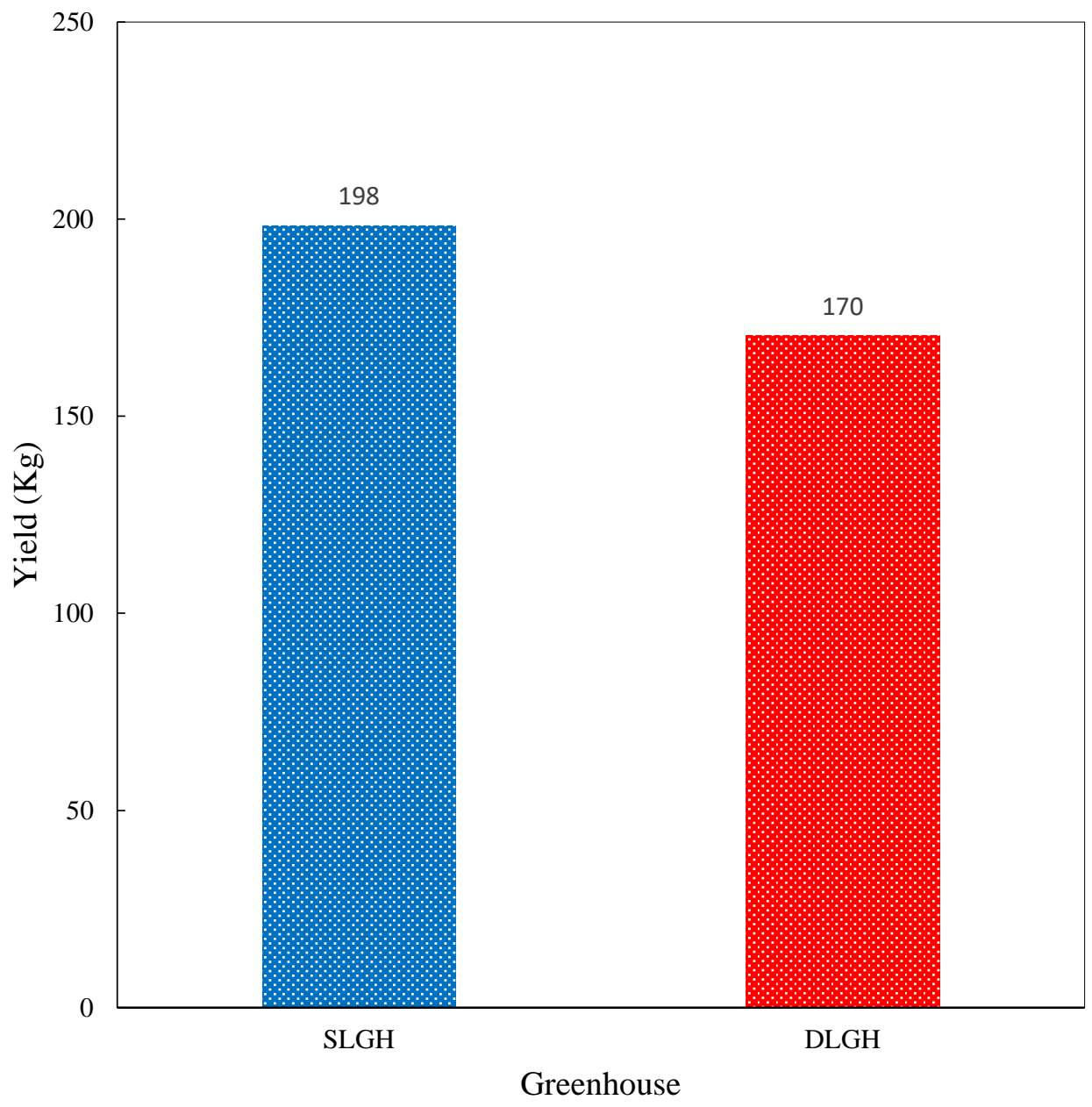

Figure 23. Strawberry yield per greenhouse.

Table 3. Descriptive statistics of marketable yield (Kg) obtained in SLGH and DLGH.

\begin{tabular}{ccccc}
\hline Groups & Sum & Mean & Variance & SD \\
\hline SLGH & 198.2 & 39.6 & 962.5 & 31.0 \\
DLGH & 169.8 & 33.9 & 308.0 & 17.6 \\
\hline
\end{tabular}

Figure 24 shows the fuel consumption from December to February in the two greenhouses. Energy consumption in both greenhouses was the highest in January and February 2021, when the outside air temperature was the lowest. It was observed that as the outside air temperature increased, heating demand decreased. The temperature and VPD analysis of variance showed no significant difference between the environmental conditions in the SLGH and DLGH. This can be attributed to the frequent heating observed in the SLGH to maintain the temperature within the recommended range, resulting in higher fuel consumption during winter. The fuel consumption in the SLGH and DLGH was 486.9 and $307.7 \mathrm{~L}$, and the mean consumption per day was $5.5 \pm 3.9 \mathrm{~L}$ and $3.5 \pm 2.5 \mathrm{~L}$, respectively. The DLGH consumed $\sim 180 \mathrm{~L}$ less fuel than SLGH, saving $~ 37 \%$ energy due to the insulation provided by the inner polyethene layer. Akpenpuun et al. [5] reported that although the SLGH system is economical for construction costs, it demands higher heating than the DLGH system. These researchers concluded that since the service life of the inner polyethene layer in the DLGH system, whose estimated cost of buying and installation was USD85, is approximately three years the choice of the DLGH is the most appropriate for energy saving and reduction in the cost of production. 


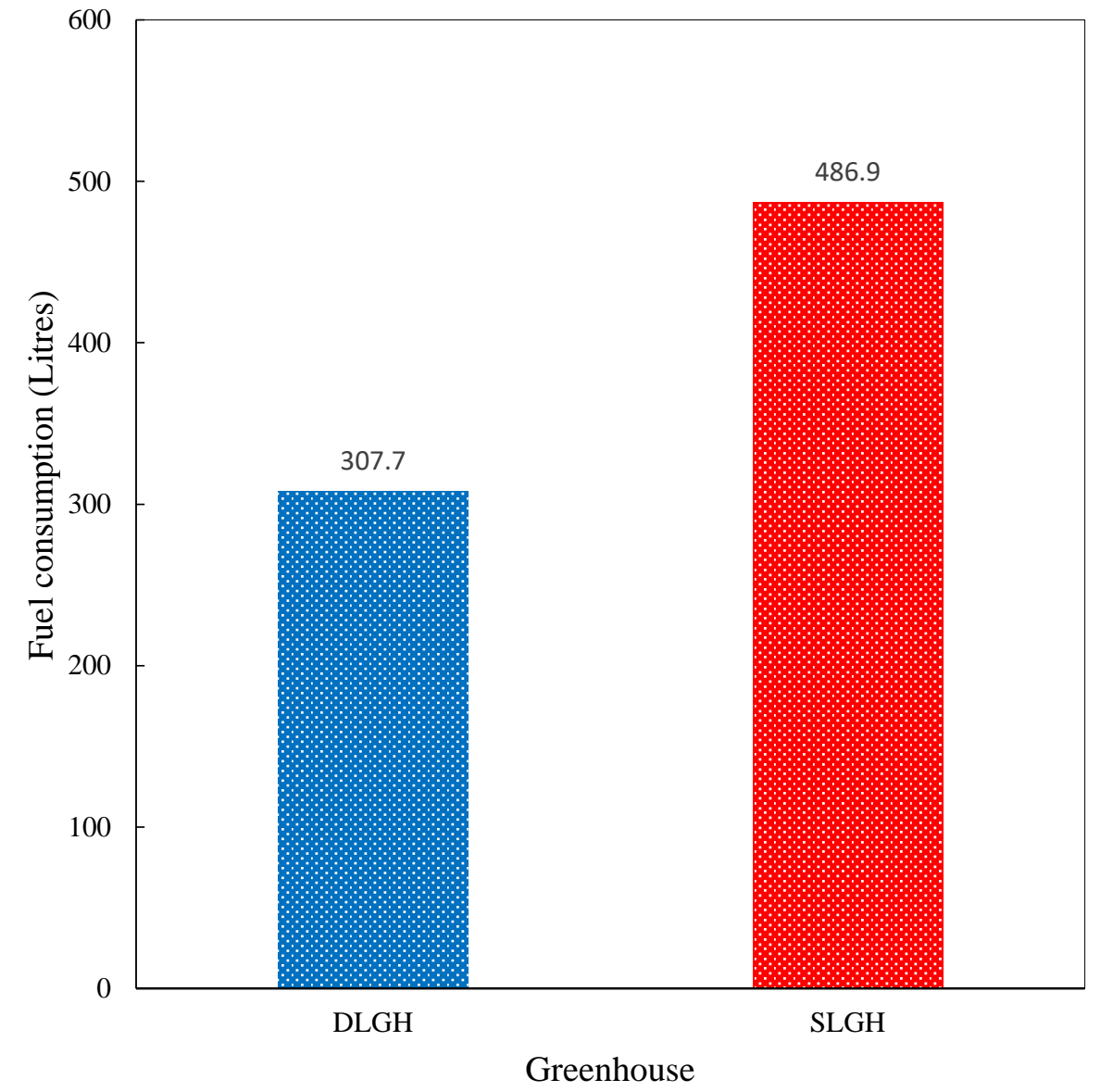

Figure 24. Total fuel consumption by the greenhouses.

Table 4 presents the cost analysis of operating the SLGH and DLGH for the cultivation of strawberries in the winter. A margin of $\$ 139.26$ was recorded between the net income recorded from the SLGH and DLGH systems.

Table 4. Strawberry p-roduction income and expenses.

\begin{tabular}{|c|c|c|c|c|c|}
\hline & & \multicolumn{2}{|c|}{ Single Layer Greenhouse } & \multicolumn{2}{|c|}{ Double Layer Greenhouse } \\
\hline & Unit Price (USD) & Quantity & Cost (USD) & Quantity & Cost (USD) \\
\hline Strawberry yield & $8.81^{* *}$ & $198 \mathrm{~kg}$ & 1744 & $170 \mathrm{~kg}$ & 1498 \\
\hline Fuel consumption & $1.07^{* * *}$ & $486.9 \mathrm{~L}$ & -520.98 & $307.7 \mathrm{~L}$ & -329.24 \\
\hline Glazing material cost & * & * & * & $\begin{array}{c}\text { PE film } \\
0.15 \mathrm{~mm} \times 8 \mathrm{~m} \times 18 \mathrm{~m}\end{array}$ & -85 \\
\hline Income (USD) & & \multicolumn{2}{|c|}{1223.02} & 1083.76 & \\
\hline
\end{tabular}

*-Not available; **-Korea Rural Economic Institute (2021); ***-Korea National Oil Corporation (2021).

The correlation coefficients ( $r$-value) of temperature, RH, VPD, and SR with yield in SLGH were $0.6,0.9,0.3$, and -0.9 , and in DLGH were $0.6,0.9,0.3$, and -0.9 , respectively. From the results obtained for both greenhouses, temperature and RH had positive and strong linear relationships with the yield, and VPD had a positive but weak linear relationship with the yield. In contrast, SR had a negative but linear relationship with yield. The positive and linear relationship of temperature, RH, and VPD with yield means that an increase in temperature, RH, and VPD will increase yield. The opposite will happen for SR, which had a negative and strong relationship with yield.

The date of the $t$-tests conducted on the SLGH and DLGH revealed that the $t$-statistics for temperature, RH, VPD, and SR were 11.45, 10.62, 11.59, and 6.89, and 11.40, 10.52, 
11.55 , and 6.48 , respectively, with a $t$-critical two-tail value of 1.98 for all parameters. The probability value ( $p$-value) of $<0.01$ was obtained for all parameters considered; therefore, the environmental parameters significantly affected the yield in both greenhouses.

\section{Conclusions}

The high demand for quality agricultural products necessitated practicing various methods and strategies of modern technologies, such as automation and mechanization, in different scopes of plant cultivation systems. Consequently, this study investigated a single outer polyolefin layer and thermal screen glazed gothic greenhouse (the SLGH) and a single polyolefin layer (outer layer), thermal screen (middle layer), and polyethene (inner layer) glazed gothic greenhouse (the DLGH). The best combination of cladding materials and thermal screens was evaluated for the microclimatic conditions (air temperature, $\mathrm{RH}$, VPD, and SR) of the greenhouses to determine the most suitable greenhouse environment system for strawberry cultivation in winter.

The following conclusions can be drawn from comparing the environmental parameters in the two greenhouse systems, the resultant crop yield, and the operation cost.

i The yield obtained in both greenhouses was insignificantly different; however, the yield in SLGH was $14 \%$ higher than the yield in DLGH;

ii The VPD percentage within the recommended range was more in the SLGH than the DLGH;

iii The SLGH can be used instead of the DLGH, saving construction costs regarding installing the second layer; however, the operating cost of the SLGH system was higher.

It was observed that the mode of retraction of the thermal screen in both greenhouses obstructed SR penetration. It is, therefore, recommended to investigate another thermal screen retraction method that will not reduce the level of SR penetration into the greenhouses.

Author Contributions: Conceptualization, T.D.A., W.-H.N., H.-T.K. and H.-W.L.; methodology, T.D.A., W.-H.N., H.-W.L., Q.O.O., A.R., M.A.A. and K.S.A.; resources, H.-W.L.; writing-original draft preparation, T.D.A., W.-H.N. and H.-W.L.; writing-review and editing, T.D.A., W.-H.N., H.-T.K. and H.-W.L.; supervision, H.-W.L. All authors have read and agreed to the published version of the manuscript.

Funding: This work was supported by Korea Institute of Planning and Evaluation for Technology in Food, Agriculture, Forestry (IPET) through Agriculture, Food and Rural Affairs Convergence Technologies Program for Educating Creative Global Leader, funded by the Ministry of Agriculture, Food and Rural Affairs (MAFRA) (717001-7). Basic Science Research Program supported this research through the National Research Foundation of Korea (NRF) funded by the Ministry of Education (NRF-2019R1I1A3A01051739).

Institutional Review Board Statement: Not applicable.

Informed Consent Statement: Not applicable.

Data Availability Statement: Data available on request due to restrictions.

Conflicts of Interest: The authors have no conflicting financial or other interests.

\section{References}

1. Jayasekara, S.N.; Na, W.H.; Owolabi, A.B.; Lee, J.W.; Rasheed, A.; Kim, H.T.; Lee, H.W. Comparison of Environmental Conditions and Insulation Effect between Air Inflated and Conventional Double Layer Greenhouse. Prot. Hortic. Plant Fact. 2018, $27,46-53$. [CrossRef]

2. Gruda, N. Impact of Environmental Factors on Product Quality of Greenhouse Vegetables for Fresh Consumption. Plant Sci. 2007, 24, 227-247. [CrossRef]

3. Taki, M.; Rohani, A.; Rahmati-Joneidabad, M. Solar thermal simulation and applications in greenhouse. Inf. Process. Agric. 2018, 5, 83-113. [CrossRef]

4. Frantz, J.M.; Ritchie, G.; Cometti, N.N.; Robinson, J.; Bugbee, B. Exploring the limits of crop productivity. Beyond the limits of tipburn in lettuce. J. Am. Soc. Hortic. Sci. 2004, 129, 331-338. [CrossRef] 
5. Akpenpuun, T.D.; Na, W.H.; Ogunlowo, Q.O.; Rabiu, A.; Adesanya, M.A.; Addae, K.S.; Kim, H.T.; Lee, H.-W. Effect of glazing configuration as an energy-saving strategy in naturally ventilated greenhouses for strawberry ("Seolhyang" sp.) cultivation. J. Agric. Eng. 2021, 52, 1-8. [CrossRef]

6. Casierra-Posada, F.; Torres, I.D.; Blanke, M.M. Fruit Quality and Yield in Partially Defoliated Strawberry Plants in the Tropical Highlands. Gesunde Pflanz. 2013, 65, 107-112. [CrossRef]

7. Martinez-Ferri, E.; Ariza, M.T.; Dominguez, P.; Medina, J.J.; Miranda, L.; Muriel, J.L.; Montesinos, P.; Rodriguez-Diaz, J.A.; Soria, C. Cropping Strawberry for Improving Productivity and Environment Sustainability. In Strawberries: Cultivation, Antioxidant Properties and Health Benefit Nutrition and Diet Reseach Progress; Malone, N., Ed.; Nova Science Publishers, Inc.: New York, NY, USA, 2014; pp. 1-20.

8. Ogunlowo, Q.O.; Akpenpuun, T.D.; Na, W.H.; Rabiu, A.; Adesanya, M.A.; Addae, K.S.; Kim, H.T.; Lee, H.-W. Analysis of heat and mass distribution in a single- and multi-span greenhouse microclimate. Agriculture 2021, 11, 891. [CrossRef]

9. American Society of Agricultural Engineers. Heating, Ventilating and Cooling Greenhouses ANSI/ASAE Standard EP406.3; American Society of Agricultural and Biological Engineers (ASABE): St. Joseph, MI, USA, 2003.

10. Harel, D.; Fadida, H.; Slepoy, A.; Gantz, S.; Shilo, K. The Effect of Mean Daily Temperature and Relative Humidity on Pollen, Fruit Set and Yield of Tomato Grown in Commercial Protected Cultivation. Agronomy 2014, 4, 167-177. [CrossRef]

11. Wang, S.Y.; Lin, H. Effect of plant growth temperature on membrane lipids in strawberry (Fragaria $x$ ananassa Duch.). Sci. Hortic. 2006, 108, 35-42. [CrossRef]

12. Li, H.; Li, T.; Gordon, R.J.; Asiedu, S.K.; Hu, K. Strawberry plant fruiting efficiency and its correlation with solar irradiance, temperature and reflectance water index variation. Environ. Exp. Bot. 2010, 68, 165-174. [CrossRef]

13. Shamshiri, R.; Ismail, W.I.W. A Review of Greenhouse Climate Control and Automation Systems in Tropical Regions. J. Agric. Sci. Appl. 2013, 2, 175-183. [CrossRef]

14. Amani, M.; Foroushani, S.; Sultan, M.; Bahrami, M. Comprehensive review on dehumidification strategies for agricultural greenhouse applications. Appl. Therm. Eng. 2020, 181, 115979. [CrossRef]

15. Lieten, P. The effect of humidity on the performance of greenhouse grown strawberry. Acta Hortic. 2002, 567, 479-482. [CrossRef]

16. Khalid, S.; Qureshi, K.M.; Hafiz, I.A.; Khan, K.S.; Qureshi, U.S. Effect of organic amendments on vegetative growth, fruit and yield quality of strawberry. Pak. J. Agric. Resour. 2013, 26, 104-112.

17. Palencia, P.; Martinez, F.; Medina, J.J.; Vazquez, E.; Flores, F.; Lopez-Medina, J. Effect of climate change on strawberry production. Acta Hortic. 2009, 838, 51-54. [CrossRef]

18. Cayli, A. Temperature and relative humidity spatial variability: An assessment of the environmental conditions inside greenhouses. Fresenius Environ. Bull. 2020, 29, 4954-4962.

19. Baeza, E.; Hemming, S.; Stanghellini, C. Materials with switchable radiometric properties: Could they become the perfect greenhouse cover? Biosyst. Eng. 2020, 193, 157-173. [CrossRef]

20. Frangi, P.; Piatti, R.; Amoroso, G. Evaluation of different screens for energy saving in the greenhouse. Acta Hortic. 2011, 893, 275-280. [CrossRef]

21. Rasheed, A.; Lee, J.W.; Lee, H.W. Evaluation of Overall Heat Transfer Coefficient of Different Greenhouse Thermal Screens Using Building Energy Simulation. Prot. Hortic. Plant Fact. 2018, 27, 294-301. [CrossRef]

22. Yano, A.; Cossu, M. Energy sustainable greenhouse crop cultivation using photovoltaic technologies. Renew. Sustain. Energy Rev. 2019, 109, 116-137. [CrossRef]

23. Bakar, N.N.A.; Hassan, M.Y.; Abdullah, H.; Rahman, H.A.; Abdullah, M.P.; Hussin, F.; Bandi, M. Energy efficiency index as an indicator for measuring building energy performance: A review. Renew. Sustain. Energy Rev. 2015, 44, 1-11. [CrossRef]

24. Rasheed, A.; Lee, J.W.; Lee, H.W. Development of a model to calculate the overall heat transfer coefficient of greenhouse covers Span. J. Agric. Res. 2018, 15, e0208. [CrossRef]

25. Bradford, E.; Hancock, J.F.; Warner, R.M. Interactions of Temperature and Photoperiod Determine Expression of Repeat Flowering in Strawberry. Hortic. Sci. 2010, 135, 102-107. [CrossRef]

26. Fernandez, G.; Butler, L.; Louws, F. Strawberry Growth and Development in an Annual Plasticulture System. Hortic. Sci. 2001, 36, 1219-1223. [CrossRef]

27. Tang, Y.; Ma, X.; Li, M.; Wang, Y. The effect of temperature and light on strawberry production in a solar greenhouse. Sol. Energy 2020, 195, 318-328. [CrossRef]

28. Kim, S.K.; Jeong, M.S.; Park, S.W.; Kim, M.J.; Na, H.Y.; Chun, C.H. Improvement of runner plant production by increasing photosynthetic photon flux during strawberry transplant propagation in a closed transplant production system. Korean J. Hortic. Sci. 2010, 28, 535-539.

29. Kacira, M.; Sase, S.; Okushima, L. Optimization of vent configuration by evaluating the greenhouse and plant canopy ventilation rates under wind induced ventilation. Trans. Am. Soc. Agric. Eng. 2004, 47, 2059-2067. [CrossRef]

30. Rouphaela, Y.; Kyriacoub, M.C.; Petropoulosc, S.A.; Pascalea, S.D.; Collad, G. Improving vegetable quality in controlled environments. Sci. Hortic. 2018, 234, 275-289. [CrossRef]

31. Kittas, C.; Karamanis, M.; Katsoulas, N. Air temperature regime in a forced ventilated greenhouse with rose crop. Energy Build. 2005, 37, 807-812. [CrossRef]

32. Sabir, N.; Singh, B. Protected cultivation of vegetables in global arena: A review. Indian J. Agric. Sci. 2013, 83, 123-135. 
33. Kroggel, M.; Kubota, C. Controlled environment strategies for tipburn management in greenhouse strawberry production. Acta Hortic. 2017, 1156, 529-536. [CrossRef]

34. Katsoulas, N.; Kittas, C. Impact of Greenhouse Microclimate on Plant Growth and Development with Special Reference to the Solanaceae. Eur. J. Plant Sci. Biotechnol. 2008, 2, 31-444.

35. Shamshiri, R.R.; Jones, J.W.; Thorp, K.R.; Ahmad, D.; Che Man, H.; Taheri, S. Review of optimum temperature, humidity, and vapour pressure deficit for microclimate evaluation and control in greenhouse cultivation of tomato. Int. Agrophys. 2018, 32, 287-302. [CrossRef]

36. Rosales, M.A.; Cervilla, L.M.; Eva, S.; Juan, J.R.; Rubio-Wilhelmi, M.; Soriano, T. The effect of environmental conditions on nutritional quality of cherry tomato fruits: Evaluation of two experimental Mediterranean greenhouses. J. Sci. Food Agric. 2011, 91, 152-162. [CrossRef] [PubMed]

37. Quinn, M.J.; May, M.L.; Dilorenzo, N.; Ponce, C.H.; Smith, D.R.; Parr, S.L.; Galyean, M.L. Effects of roughage source and distillers grain concentration on beef cattle fnishing performance, carcass characteristics, and in vitro fermentation. J. Anim. Sci. 2011, 89, 2631-2642. [CrossRef] [PubMed]

38. Speetjens, B.; Hemming, S.; Wang, D.; Tsay, J. Design of a Vegetable Greenhouse System for Subtropical Conditions in Taiwan; Wageningen UR Greenhouse Horticulture: Wageningen, The Netherlands, 2012. Available online: https://edepot.wur.nl/238571 (accessed on 3 December 2021).

39. Iraqi, D.; Gagnon, S.; Dubé, S.; Gosselin, A. Vapour pressure deficit (VPD) effects on the physiology and yield of greenhouse tomato. Hortic. Sci. 1995, 30, 846.

40. Zolnier, S.; Gates, R.S.; Buxton, J.; Mach, C. Psychrometric and Ventilation Constraints for Vapor Pressure Deficit Control. Comput. Electron. Agric. 2000, 26, 343-359. [CrossRef]

41. Ting, K.C.; Giacomelli, G.A. Availability of Solar Photosynthetically Active Radiation. Trans. ASAE 1987, 30, 1453-1457. [CrossRef]

42. Yoshida, H.; Mizuta, D.; Fukua, N.; Hikosaka, S.; Goto, E. Effects of varying light quality from single-peak blue and red lightemitting diodes during nursery period on flowering, photosynthesis, growth, and fruit yield of everbearing strawberry. Plant Biotechnol. 2016, 33, 267-276. [CrossRef]

43. Hidaka, K.; Dan, K.; Imamura, H.; Miyoshi, Y.; Takayama, T.; Sameshima, K.; Kitano, M.; Okimura, M. Effect of Supplemental Lighting from Different Light Sources on Growth and Yield of Strawberry. Environ. Control Biol. 2013, 51, 41-47. [CrossRef]

44. Faust, J.E.; Holcombe, V.; Rajapakse, N.C.; Layne, D.R. The Effect of Daily Light Integral on Bedding Plant Growth and Flowering. Hortic. Sci. 2005, 40, 645-649. [CrossRef]

45. Zhao, Y.; Teitel, M.; Barak, M. Vertical temperature and humidity gradients in a naturally ventilated greenhouse. J. Agric. Eng. Res. 2001, 78, 431-436. [CrossRef]

46. Akpenpuun, T.D.; Mijinyawa, Y. Evaluation of a Greenhouse Under Tropical Conditions Using Irish Potato (Solanum tuberosum L.) as the Test Crop. ACTA Technol. Agric. 2018, 21, 56-62. [CrossRef] 